2. To: (Receiving Organization) SST Retrieval Projects

5. Proj./Prog./Dept./Div.:

W-320 / 8C620

8. Originator Remarks:

Supporting Document Approval and Initial Release

11: Receiver Remarks:

[] Yes

[X] No
11A. Design Basel ine Document?

4. Related EDT No.: 6010549

7. Purchase Order Non:

N/A

9. Equip./Component No.:

AY-Farm Electrical

10. System/8ldg./Facility: 241-C-106

12. Major Assm. Dwg. No.: $17-2-818693$

13. Permit/Permit Application No.: $N / A$

14: Required Response Date: $N / A$

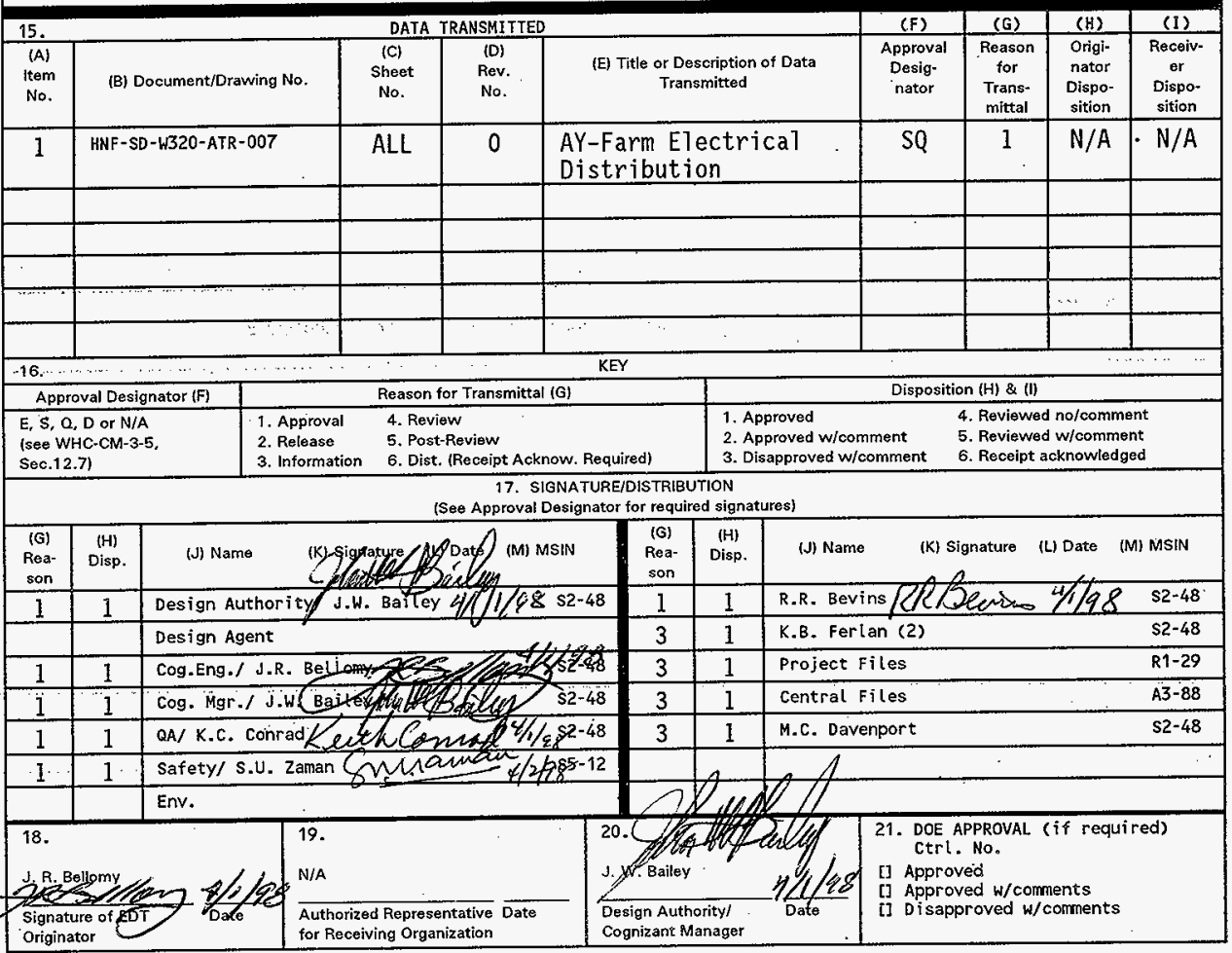

BD-7400-172-2 (05/96) GEF097 


\title{
PROJECT $W$-320 ACCEPTANCE TEST REPORT FOR AY-FARM ELECTRICAL DISTRIBUTION
}

\author{
R. R. Bevins
}

Numatec Hanford Corporation

U.S. Department of Energy Contract DE-AC06-96RL13200

EDT/ECN: 622193

Org Code: $8 \mathrm{C} 470$

UC: 510 ,

B\&R Code: EW3130010

Charge Code: D2MEP

Total Pages: 50

Koms $4 / 2 / 188$

Key Words: 241-C-106, Project $W-320$, Sluicing, AY-Farm Electrical

Abstract: Project W-320 Acceptance Test Report for AY-Farm Electrical Distribution

TRADEMARK DISCLAIMER. Reference herein to any specific commercial product, process, or service by trade name, trademark, manufacturer, or otherwise, does not necessarily constitute or imply its endorsement, recomendation, or favoring by the United States Government or any agency thereof or its contractors or subcontractors.

Printed in the United States of America. To obtain copies of this document, contact: Document control Services, P.O. Box 950, Mailstop H6-08, Richland WA 99352, Phone (509) 372-2420;

Fax (509) 376-4989.
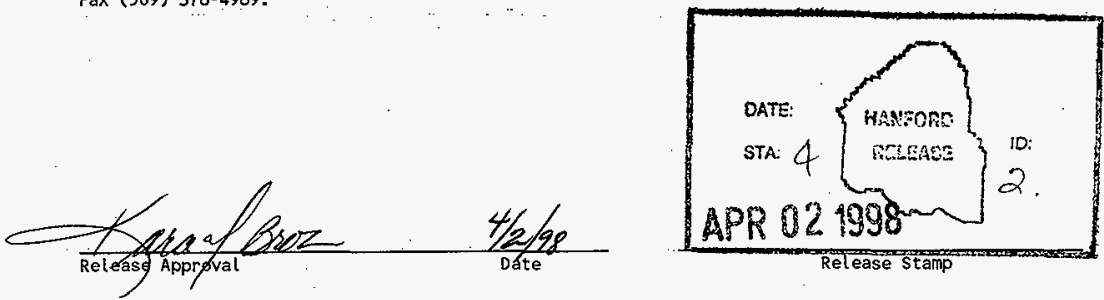

Approved for Public Release 


\title{
AY-Farm Electrical Distribution
}

\author{
J. R. Bellomy
}

Westinghouse Hanford Company, Richland, WA 99352

U.S. Department of Energy Contract DE-AC06-87RL10930

\begin{tabular}{|c|c|c|}
\hline $\begin{array}{l}\text { EOT/ECN: } \\
\text { Org Code: } \\
\text { B\&R Code: }\end{array}$ & $\begin{array}{l}606549 \\
73532 \\
E W 3130010\end{array}$ & $\begin{array}{l}\text { UC: } 510 \\
\text { Charge Code: } \\
\text { Total Pages: }\end{array}$ \\
\hline
\end{tabular}

Key Words: 241-C-106, Project W-320, STuicing, AY-Farm Electrical

Abstract: Project W-320 Acceptance Test Procedure for AY-Farm Electrical Distribution.

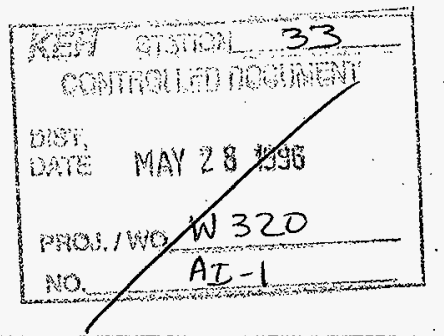

TRADEMARK DISCLAIMER. Reference herein to any specific comercial prodert, process, or service by trade name, trademark, manufacturer, or otherwise, does not necessarily const itute or inply its endorsenent, recompendation, or favoring by the United states Government or amy agency thereof or its contrsetors or subcontractors.

Printed in the United States of Aweries, Yo obtain copies of this document, contact: MHC/BCS

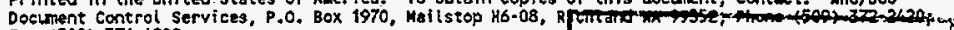
Fax (509) 376.4989.
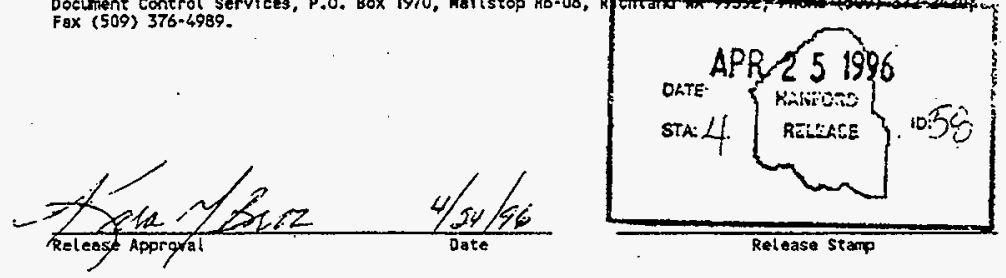

\section{Approved for Public Release}


ACCEPTANCE TEST PROCEDURE KHC-SD-H320-ATP-CAT

TEST TITLE AY-Farm Electrical Distribution System

LOCATION AY-Farm

PROJECT NUMBER $H-320$

WORK ORDER ER6159

PROJECT TITLE H-320 Tank 24]-C-106 STuicing

Prepared By

ICF Kaiser Hanford Company

Richland, Washington

For Westinghouse Hanford Company

Subcontract HHC-380393.

PROCEOURE APPROYAL

ICF KAISER HANFORO COMPANY (ICF KH)

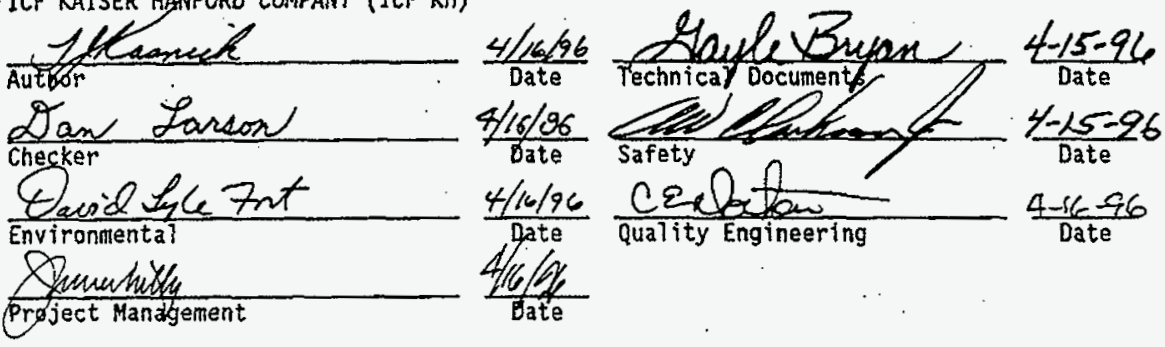

Westinghouse Hanford Company (WHC)

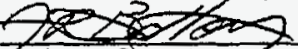

Projects Departiont
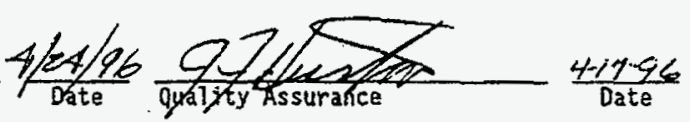

i. +7.24 .96$

Safety

$$
\begin{gathered}
\text { Eev's Incoupdeated } \\
\text { w-320- } 4.09 \\
427 \\
443 \\
545 \\
661
\end{gathered}
$$

H320007.ATP. 2558 


\section{EXECUTED BY}

Watanentar

Tost Director/grganization

Retordegorganization

$\frac{11 / 4 / 97}{\text { Date }} \frac{\text { whlem }}{\text { Test Operator Organization }} \frac{11-4-97}{\text { Date }}$ $\frac{1 / 4 / 57}{\text { Date }}$

WITNESSES

Witness/organization

Witness/Organization

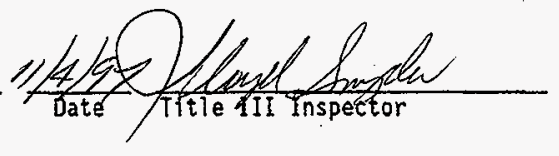

$\frac{11 / 4 / 92}{\text { Date }}$

Date Witness/Organization

Date

A-E APPROVAL:

ICF Kaiser Hanford Company (ICF KH)
Without
exceptions
With exceptions
resolved
X
With exceptions
outstanding

Kanl 7. Decine

Project.Manager
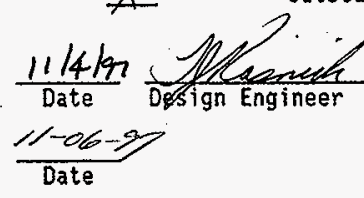

$\frac{11 \text { (y/92 }}{\text { Date }}$

TEST APPROVAL AND ACCEPTANCE

Westinghouse Hanford Company

Without

exceptions
With exceptions resolved

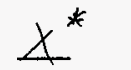

With exceptions outstanding

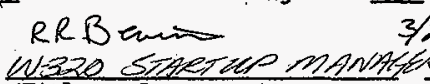

ofte (Tit)e or Department)

(Titie or Department)

w320 peotect ppentocke

(Title or Department)

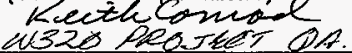

(Titie or Department)
Date $\frac{3 / 25 / 58}{\text { Date }}$

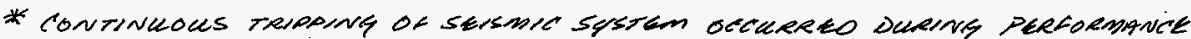

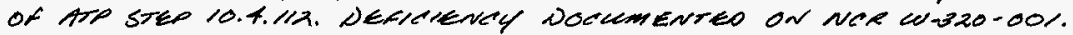

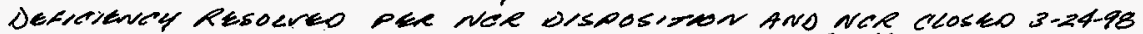


TITLE/PROCEDURE APPROVA:

PURPOSE

REFERENCES

CHANGE CONTROL

NOTE: At completion of tesi, enter pages added during performance of test to this Table of Conienis. 
This Acceptance Test Procedure (ATP) has been prepared to demonstrate that tise AY-Farm Electrical Distribution System functions as required by the design criteria. This test is divided into three parts to support the planned construction schedule; Section 8 tests Mini-Power Panel AY102-PPI and the EES; Section 9 tests the SSS support systems; Section 10 tests the SSS and the Multi-Pak Group Control Panel. This test does not include the operation of end-use components (loads) supplied from the distribution system. Tests of the end-use components (loads) will be performed by other W-320 ATPS.

REFERENCES

2.1 DRAWINGS

H-2-818559, Sh 1, Rev 0 Project $W-320$ P\&ID Tank 241-AY-102

H-2-818693, Sh 1, Rev 0 . Electrical AY-Farm One-Line Diagram

(including ECNs $W-320-167$

and 257)

H-2-818695, Sh 2, Rev 1 - Electrical AY-Farm Plans and Details

H-2-818595, Sh 3, Rev I Electrical AY-Farm EES Plans and Details

H-2-818696, Sh 1, Rev O Electrical AY-Farm Seismic Shutdown Sys Elementary (including ECN $H-320-167$ ) Diagram

H-2-818696, Sh 2, Rev 0 Electrical AY-Farm Seismic Shutdown Sys Elementary (including ECN W-320-167) Diagram

H-2-818696, Sh 3, Rev 0 Electrical AY-Farm Seismic Shutdown Sys Plan \& (including $E C N$ W-320-167) Details

H-2-820751, Sh 1, Rev 0 Electrical AY-Farm One Line Diagram (including $E C N$ W-320-254)

2.2 SPECIFICATIONS

Construction Specification H-320-C7, Rev 0 Package 3 - AY Tank Farm

Procurement Specification W-320-P33, Rev 0 Electrical Equipment Skid AY-Farm (including ECNs $W-320-96,124,134$ and 152)

Procurement Specification $1-320-P 35$, Rev 0 Seismic Shutdown System (including ECNs W-320-142, 165, 175 and 212)

Procurement Specification W-320-P36, Rev 0 Enclosure, Environmental Control (including ECN W-320-143)

2.3 ENGINEERING CHANGE NOTICES (ECNS)

Prior to final test approval, markup the controlled copy of this ATP with all of the ECNs written against it. 
2.4 VENOOR INFORMATICY

File \#22668, supplenent \#LATEZ

3.1 GENERÄ.

Each company or organization participating in this ATP will designate personne: to assume the responsibilities and duties as defined herein for thein respective roles. The designees shall become familiar with this ATP and the systems involved to the extent that they can perform their assigned duties.

3.2 HHC PROJECT ENGINEER

3.2.1 Signs Execution and Test Approval page when test is complete ard accepted.

3.2.2 Provides a distribution Tist for the approved and accepted ATP.

3.3 ICF KH PROJECT. MANAGER

3.3.1 Designates a Test Director.

3.3.2 Signs Execution and Test Approval page when test is complete and accepted.

3.3.3 Signs exception form when all exceptions have been resolve:.

3.4 TEST OIRECTOR

3.4.1 Coordinates and directs acceptance testing.

3.4.2 Coordinates testing with ICF KH Utilities.

3.4.3 Coordinates testing with ICF KH Craft.

3.4.4 Distributes the approved testing schedule, to ICF KH Project Manager and WHC Project Engineer, before start of testing.

3.4.5 Notifies concerned parties (includes ICF KH Project Manager, ICF KF Lead Electrical Engineer, and WHC Project Engineer) when a change is made in the testing schedule.

3.4.6 Schedules and concucts a pretest kickoff meeting with test participants when necessary.

3.4.7 Confirms that field testing and inspection of the system or portior of the system to be tested has been completed.

3.4.8 Stops any test which, in his or her judgement, may cause damage tc the system lintil the problem has been resolyed. 
3.4.9. After verifying there is no adverse impact, may alter tine sequence in which systems or subsystems are tested.

3.4.10 If a test is to be suspended for a period of time, ensures that the system is left in a safe mode.

3.4.11 Before restarting suspended test, reverifies the test prerequisites.

3.4.12 Initjates ECNs to document required changes to the ATP.

3.4.13 Reviews recorded data, discrepancies, and exceptions.

3.4.14 Signs Execution and Test Approval page when test has been performed.

3.4.15 Takes necessary actions to clear exceptions to the test, and signs exception form when exceptions have been resolved.

3.4.16 Obtains required signatures on the ATP Master before reproduction and distribution.

3.5 WITNESSES (Provided by Participating Organizations. One witness shajl be a Title III acceptance inspector.)

3.5.1 Witnesses the tests.

3.5.2 Reviews results of testing.

3.5.3 Assists the Test Director when requested.

3.5.4 Signs Execution and Test Approval page when test has been performed.

3.5.5 Signs exception form when exception has been resolved.

3.6 RECORDER (Provided by ICF KH)

3.6.1 Prepares a field copy from the ATP Master.

3.6.2 Records names of all designated personnel on field copy of ATP before start of testing.

3.6.3 Records test instrument identification numbers and calibration expiration dates, as required.

3.6.4 Initiais and dates every test step on the field copy as it is completed next to the step number or on a Data Sheet, when provided. Records test data.

3.6.5 Records exceptions on an exception form. Uses additional exception forms as needed. Notifies the Test Director at time the exception is made.

3.6.6 Signs Execution and Test Approval page when test has been performed.

3.6.7 After test is finished, assigns alpha numeric page numbers to added data sheets and exception forms. Records page numbers in the Table of Contents.

HNF ged $/_{3 / 3} / 98$

WHE-50-W320-ATA-007

Rev 0

04/15/96 
3.6.8 Transfers Field copy entries for each step to the Master in inik cr type, signs, and dates. Transmits the completed Master to the Test Director for approval signature routing. Transmits the Field copy to Construction Document Control for inclusion in the official project file.

3.6.9 Signs exception form when exception has been resolved and transmits to Test Director.

\subsection{TEST OPERATOR}

3.7.1 Performs test under direction of the Test Director.

3.7.2 Provides labor, equipment, and test instruments required for performing tests which have not been designated as being provided by others.

3.7.3 Confirms that all equipment required for performing test will be available at the start of testing.

3.7.4 Signs the Execution and Test Approval page.

3.8 A-E ACCEPTANCE INSPECTION, DESIGN ENGINEER, AND PROJECT MANAGER

3.8.1 Evaluates results.

3.8.2 Signs for A-E Approval on Execution and Test Approval page.

4 CHANGE CONTROL

Required changes to this ATP must be processed on ECNs in accordance with company procedures. If a need for change is discovered in the course of running the test, the test shall be stopped until the ECN is approved. However, this does not prevent the running of another portion of the test. unaffected by the change.

5 EXECUTION

5.1 OCCUPATIONAL SAFETY AND HEALTH

Individuals shall carry out their assigned work in a safe manner to protect themselves and others from undue hazards and to prevent damage to property and environment. Facility line managers shail ensure the safety of activities within their areas to prevent injury, property damage, or interruption of operation. Performance of test activities shall always include safety and health aspects.

These tests involve working on or near energized equipment; all procedural requirements for working on or near energized equipment shall be followed, and an Energized Electrical Work Permit (KEH-2211.00/WHC-A-6001-687) shal 1 be completed. 
5.2 PERFORMANCE

5.2.1 Conduct testing in accordance with ICF KH Procedure CON 3.5 . (Performance and Recording of Acceptance Test Procedures).

5.2.2 Perform test following the steps and requirements of this procedure.

5.2.3 As each step in Sections $7,8,9$, and 10 are completed, the person completing the step shall initial and date in the space provided.

6 EXCEPTIONS

6.1 GENERAL

Exceptions to the required test results are sequentially numbered and recorded on individual exception forms $(\mathrm{KEH}-428)$. This enables case-by-case resolution and approval of each exception.

Errors/exceptions in the ATP jtself shall NOT be processed as test exceptions (see Section 4 CHANGE CONTROL).

\subsection{RECORDING}

6.2.1 Number each exception sequentially as it occurs and record it on an exception form.

6.2.2 Enter name and organization of the individual that identifies each exception.

6.2.3 Enter planned action to resolve each exception when such determination is made.

\subsection{RETEST/RESOLUTION}

Record the action taken to resolve each exception. Action taken may not be the same as planned action.

6.3.1 When action taken results in an acceptable retest, sign and date Retest Execution and Acceptance section of the exception form.

6.3.2 When action taken does not involve an acceptable retest, strike out the Retest Execution and Acceptance section of the exception form.

6.4 APPROVAL AND ACCEPTANCE

The Test Director provides final approval and acceptance of exceptions by checking one of the following on exception form:
6.4.1 Retest Approved and Accepted: Applicable when Retest Execution and Acceptance section is completed.
6.4.2 Exception Accepted-As-Is: Requires detafled explanation.
6.4.3 Other: Requires detailed explanation. 
The Test Director signs and dates the exception form and obtains other approvals, if required.

\subsection{DISTRIBUTION}

A copy of the approved exception form is distributed to each participant. The signed original is attached to the ATP Master.

7 PREREQUISITES, EQUIPHENT/INSTRUMENTS, AND ABBREVIATIONS

Note: This ATP was prepared based on performing a partial ATP for testing of Mini-Power Panel AY102-PP1, the EES lighting, the EES receptacles, the EES HVAC, the AY-PDP-1 light and the AY-POP-1 receptacle (Section 8), performing a partial ATP at a later date to test the SSS support systems (Section 9), and then performing a partial ATP at a later date to test the SSSs and the Multi-Pak Group Control Panel (Section 10).

\subsection{PREREQUISITES}

See Para 8.1 for prerequisites for testing the Mini-Power PaneI AYI02-PPI and the EES.

See Para 9.1 for prerequisites for testing of the SSS support systems.

See Para 10.1 for prerequisites for testing of the SSS and the Multi-Pak Group Control Pane1.

7.2 EQUIPMENT/INSTRUMENTS

See Para 8.2 for equipment/instruments required for testing the Mini-Power Panel AY102-PP1 and the EES.

See Para 9.2 for equipment/instruments required for testing of the SSS support systems.

See Para 10.2 for equipment/instruments required for testing of the SSS and the Multi-Pak Group Control Panel.

\subsection{ABBREVIATIONS}
A A phase voltage or current
B B phase voltage or current
C C phase voltage or current
ECN Engineering Change Notice
EES Electrical Equipment Skid - Building 241-AY-51
$\mathrm{H} \quad 120 \mathrm{~V}$ Hot Leg
11 First $120 \vee$ Hot Leg
L2 Second $120 \mathrm{~V}$ Hot Leg

HNF $\mathrm{geQ}_{3 / 31} / 98$

WHE-SO-W320-ATR-007

Rev 0

$04 / 15 / 96$ 


$\begin{array}{ll}\text { N } & \text { Neutra } \\ \text { PDP } & \text { Power Distribution Panel AY-POF-: } \\ \text { PP } & \text { Power Pane: } \\ \text { SSS } & \text { Seismic Shutdown Syste* } \\ \text { VOM } & \text { Volt-ohmmeter } \\ \text { VSO } & \text { Variable Speed Drive }\end{array}$


Note: If the results of any step do not agree with expectations, STOP the test and NOTIFY the Test Director.

8.1 PREREQUISITES FOR TESTING MINI-POWER PANEL AY102-PP1 AND THE EES

The following conditions shall exist at start of the testing in Section 8 of this ATP. Note that Para 9.I lists prerequisites required for performance of Section 9, and that Para 10.1 lists prerequisites required for performance of Section 10 .

f $8 / 3 / 96$

8.1.1 WHC Project Engineer has been notified 24 hours prior to start of the testing.

$8 / 3 / 96 \quad 8.1 .2$

Mini-Power Panel AY102-PP1 and the EES have been inspected for compliance with construction documents and general cleaniiness.

$48 / 3 / 96$

8.1 .3

Reference documents (including this ATP) have been verified for correct revision number and outstanding ECNs.

$8 / 3 / 96 \quad 8.1 .4$

$8 / 3 / 96 \quad 8.1 .5$

$\frac{18 / 3 / 96}{18 / 3 / 46}$

8.1 .6

8.1 .7

$18 / 3 / 96$

8.1 .8

$88 / 3 / 54.1 .9$

$48 / 3 / 96 \quad 8.1 .10$

$8 / 3 / 96$

8.1 .11

$8 / 3 / 56$

8.1 .12
A Prejob Safety Analysis has been prepared and a Prejob Safety Meeting has been conducted for this section of testing.

Test instruments have a valid calibration stamp attached. Test instrument identification numbers and calibration expiration dates have been recorded in Para 8.2 .

Grounding has been visually inspected and continuity tested.

Wiring from the AY-Farm Power Distribution Panel AY-PDP-1 to the Mini-Power Panel AY102-PPI has been continuity tested and meggered, as applicable.

Wiring has not been terminated on the load side of the Mini-Power Pane 1 AY 102-PP1 breakers $2,7,8,9,10,12,13,14,15$, and 16, or the load side wiring is lifted to prevent injury to personnel or damage to equipment.

All circuit breakers on Mini-Power Panel AY102-PPl are open (OFF position). The HVAC unit disconnect switch is open (OFF position).

Mini-Power Panel AY102-PPI feeder breaker, on Power Distribution Panel AY-PDP-1, is open (OFF position).

Power Distribution Panel AY-PDP-1 is energized.

ATl worker safety equipment required to perform test is readily available.

8.2

EQUIPMENT/INSTRUMENTS FOR TESTING MINI-POWER PANEL AYIO2-PP1 AND THE EES

Supplied by Test operator unless otherwise noted.

8.2.1 Volt-ohmmeters (VOM): $120 / 240$ to $277 / 480 \mathrm{~V}$

Instrument No. $0 / 68$

Expiration Date $7 / 26 / 87$

W320007.ATP.2558

$-11-$

HNF $\mathrm{ged}_{3} / 31,98$

WHC-5D-W320-ATA-007

Rev 0

$04 / 15 / 96$ 
8.3 CIRCUIT BREAKER RATINGS FOR MINI-POHER PANEL AY102-PP1 AND THE EES

8.3.1 Verify that the equipment feeder breakers on EES Mini-Power Panel AY102-PPI have the correct trip ratings as follows:

\begin{tabular}{|c|c|c|}
\hline BREAKER & 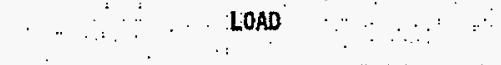 & $\begin{array}{l}\text { TRIP. RATING } \\
\text { :(AMPS) }\end{array}$ \\
\hline$A Y-P D P-1 / \# 7$ & Mini-Power Panel AY102-PPl & 70 \\
\hline $\begin{array}{c}\text { Panelboard } \\
\text { Primary } \\
\text { MAIN }\end{array}$ & Mini-Power Panel AY102-PPl Input & 60 \\
\hline $\begin{array}{c}\text { Panel board } \\
\text { SECONDARY } \\
\text { MAIN }\end{array}$ & Panelboard AY102-PPI & 80 \\
\hline $\begin{array}{l}\text { Pane } 1 \text { board ckts } \\
1,2,4,7,8, \\
9,10,11,12, \\
13,14,15 \& 16\end{array}$ & Various loads and spares & 20 \\
\hline $\begin{array}{c}\text { Panel board ckts } \\
5 \leqslant 6\end{array}$ & $\begin{array}{l}\text { 241-AY-51B RCPT \& HVAC; } \\
241-A Y-51 A \text { RCPT \& HVAC }\end{array}$ & 30 \\
\hline
\end{tabular}

8.4 MEASUREMENTS - MINI-POWER PANEL AY102-PP1 AND THE EES

CAUTION: Observe proper electrical safety precautions around energized equipment in accordance with WHC-CM-1-10, WKS 15, Electrical Hork Safety.

Note: Steps 8.4.1 through 8.4.20 involve testing Mini-Power Pane] AY102-PP1 and $i$ ts breakers, the EES lighting and receptacles, the EES HVAC unit, the $A Y-P D P-1$ light, and the $A Y-P D P-1$ receptacle.

$18 / 3 / 96$

Using the IQ Data meter on $A Y-P D P-1$, read and record $V_{A B}, V_{B C}$, and $V_{C A}$ y $8 / 3 / 96$

\section{4 .2}

Close the Mini-Power Panel AY102-PP1 feeder breaker AY-PDP-1/\#7 (ON position).

f| $2 / 3 / 97$

8.4 .3

Tha Amligablo

Using the VOM, measure that-all-3 phase-to-phase voltages-on (the load forson Stof Mini-Power Panel AY102-PPI feeder breaker AY-PDP-1/ $\$ 7$.

$2 / 3 / 97$ Record the values of $V_{A B}, V_{B C}$, and $V_{C A}$ on the Data Sheet.

ELN $54+245$ Verify that the voltages in the preceding step agree $( \pm 2 \mathrm{~V}$ ac) with the voltages from the IQ Data meter in Step 8.4.1 and in the range- of 480 to $504-V$-ae.

8.4.5 Close the panelboard AY102-PPI PRIMARY MAIN breaker (ON position). 8.4.6 Close the panelboard AY102-PPI SECONDARY MAIN breaker (ON position). 
Using the VoM, measure the line-to-line voltage and both line-to-neutral voltages in the panelboard. Record the values of $V_{L L}, V_{L I N}$, and $V_{L 2 N}$ on the Data Sheet.

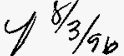

8.4 .9

4 $8 / 3 / 96$

8.4 .10

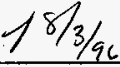

8.4 .11

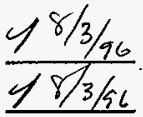

8.4 .12

8.4 .13

$8 / 3 / 968.4 .14$

$8 / 3 / 568.4 .15$

8.4 .16

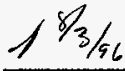

8.4.16.1

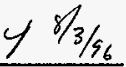

8.4 .16 .2

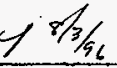

8.4 .16 .3

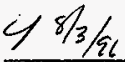

8.4 .16 .4

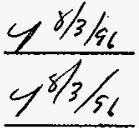

8.4 .17

8.4 .18

Yerify that the panelboard 7 ine-to-line voltage is in the range of 240 to $252 \vee$ ac and that the panelboard inne-to-neutral voltages are in the range of 120 to $126 \mathrm{~V}$ ac.

Close panelboard breaker for EES lighting and EES receptacles AY102-PP1/ $\$ 4$ (ON positions).

Verify that the EES light fixtures function properly using the toggie switch. Verify that the pilot light is ILLUMINATED when the interior light fixtures are ILLUMINATED.

Using the VOM, measure and verify the voltage at each of the three EES duplex receptacles is in the range of 120 to $126 \mathrm{~V}$ ac. Verify that the GFCI feature of the applicable duplex receptacle functions properly via the test and reset buttons.

Set the EES HVAC unit (AC-0623) thermostat controls to OFF.

Close the EES HVAC unit (AC-0623) feeder breaker AY102-PP1/\#1 (ON position).

Using the YOM, measure and verify that the line-to-line voltage on the line side of the HVAC unit disconnect switch, located in a side panel of the HVAC unit, is in the range of 240 to $252 \mathrm{~V}$ ac.

Close the EES HVAC unit (AC-0623) disconnect breaker (located on the side of the HVAC unit) (ON position).

Verify that the EES HYAC unit (AC-0523) functions properly by adjusting the thermostat controls as follows:

Set the EES HVAC unit (AC-0623) thermostat controls to automaticaily maintain 50 to $70^{\circ} \mathrm{F}$. Set the thermostat controls to operate in AUTO.

Raise the temperature setting enough to cause the HVAC unit to start heating the inside of the EES and allow to run for approximately 5 minutes.

Lower the temperature setting enough to cause the HVAC unit to start cooling the inside of the EES and allow to run for approximately 5 minutes.

Set the EES HVAC unit (AC-0623) thermostat controls to maintain 50 to $70^{\circ} \mathrm{F}$ in AUTO.

CTose the AY-PDP-1 LTG \& RCPT feeder breaker AY102-PP1/\#11, in the EES (ON position).

Verify that the AY-PDP-1 Tight fixture functions properly using the toggle switch on AY-PDP-1.

W320007.ATP. 2558

HNF $\mathrm{ged}_{3 / 31} 198$

WHE-SD-W320-ATR-007

Rev 0

04/15/96 
8.4.19 Using the VOM, measure and verify the voltage at the AY-POP-1 duplex receptacle is in the range of 114 to $126 \mathrm{~V}$ ac. Verify that the GFCI feature of the duplex receptacle functions properiy via the test and reset buttons.

8.4.20 For each 20 A feeder breaker in panelboard AY102-PP1, except circuits $\# 1$, \#4, and \#11: Close the breaker, use the VOM on the load side of the breaker to verify the line-to-neutra? voltage is in the range of 120 to $126 \mathrm{~V} \mathrm{ac}$, and then open the breaker.

$18 / 3 / q_{1}$ 8.4.21 Reconnect any wiring that was lifted, from the load side of the $120 / 8$ $18 / 3 / 26$ feeder breakers on Mini-Power Panel AY102-PP1, due to this procedure. 8.4.22 Perform the Final Equipment Lineup in Step 8.5

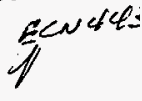

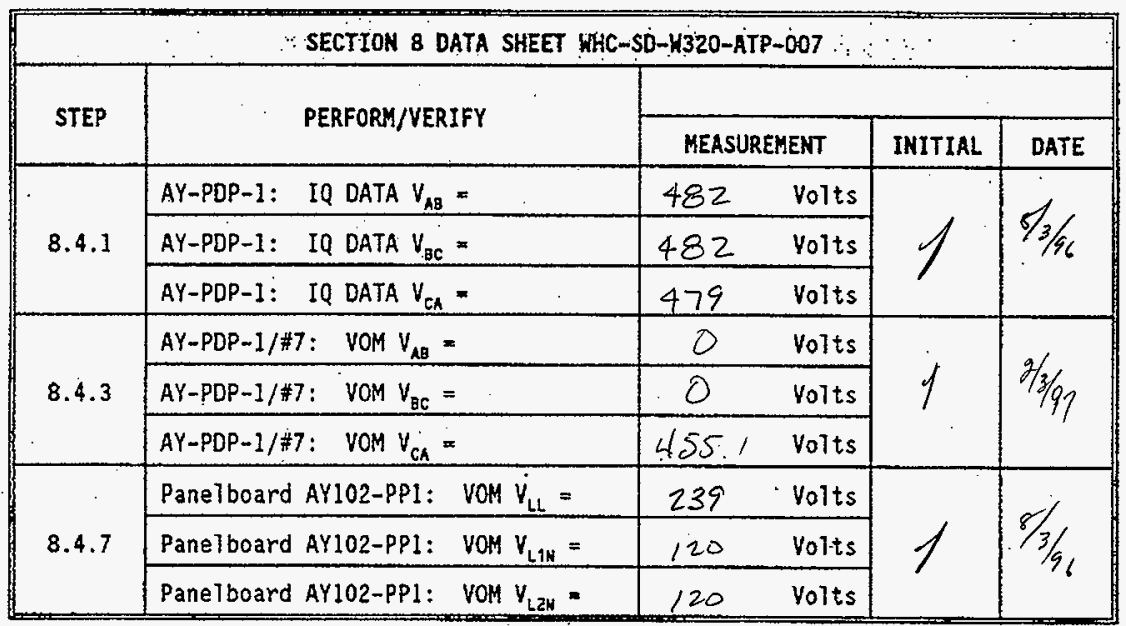

HNF ${ }_{3 / 31 / 98}$

WHE-SO-W320-ATR-007

Rev 0

$04 / 15 / 96$ 
8.5 FINAL EQUIPMENT LINEUP FOR TESTING MINI-POWER PANEL AYIO2-PPI AND THE EES

Upon completion of the testing steps in Section 8 , the status of the equipment used in this Section of the ATP should be as shown in the following table. If any of the equipment is not in the required condition, notify the Test

Director. The Test Director will determine the appropriate action.

\begin{tabular}{|c|c|c|c|}
\hline \multicolumn{4}{|c|}{ SECTIOH 8 FINAL EQUIPMENT LINEUP WHC-SD-W320-ATP-007 } \\
\hline LOCATION & PERFORM/VERIFY & IHITIAL. & DATE \\
\hline$A Y-P D P-1 / \$ 7$ & Mini-Power Panel AY102-PP1 feeder breaker: ON & H & $8 / 3 / 46$ \\
\hline EES & $\begin{array}{l}\text { Mini-Power Pane] AY102-PP1 PRIMARY MAIN breaker: } \\
\text { ON }\end{array}$ & & $8 / 3 / 96$ \\
\hline EES & $\begin{array}{l}\text { Mini-Power Panel AY]02-PP1 SECONDARY MAIN } \\
\text { breaker: ON }\end{array}$ & & $\gamma / 3 / 5 i$ \\
\hline EES & AY102-PP.1 circuit breakers $\# 1$, \#4, \#11: ON & $\mathscr{H}$ & $8 / 3 / 46$ \\
\hline EES & $\begin{array}{l}\text { AY102-PP1 circuit breakers } \# 2, \# 5, \# \sigma, \# 7, \# 8, \\
\# 9, \# 10, \# 12, \# 13, \# 14, \# 15, \# 16: \text { OFF }\end{array}$ & & $8 / 3 / 96$ \\
\hline EES & HVAC unit (AC-0623) local disconnect breaker: ON & 1 & $8 / 3 / 56$ \\
\hline EES & HYAC unit (AC-0623) thermostat controls: AUTO & $\mathscr{Z}$ & $8 / 3 / 86$ \\
\hline
\end{tabular}

$\gg$ END OF SECTION $8 \ll$ 
TESTING OF SSS SUPPORT SYSTEMS

Note: If the results of any step do not agree with expectations, STOP the test and NOTIFY the Test birector.

\subsection{PREREQUISITES FOR TESTING OF 555 SUPPORT SYSTEMS}

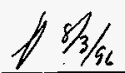

The following conditions shall exist at start of this testing.

WHC Project Engineer has been notified 24 hours prior to start of the testing.

If $8 / 3 / 56.1 .2$

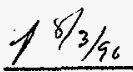

9.1 .3

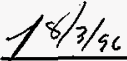

9.1 .4

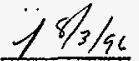

9.1 .5

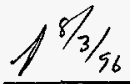

9.1 .6

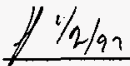

9.1 .7

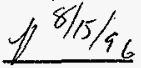

9.1 .8

Note:

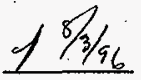

9.1 .9

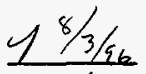

9.1 .10

9.1 .11

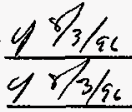

9.1 .12

9.1 .13

The Missile Shield Enclosure B1dgs 241-AY-51A and 241-AY-518, and associated wiring, have been inspected for compliance with construction documents and generat cleantiness.

Reference documents (including this ATP) have been verified for correct revision number and outstanding ECNs.

A Prejob Safety Analysis has been prepared and a Prejob Safety Meeting has been conducted for this section of testing.

Test instruments have a valid calibration stanp attached. Test instrument identification numbers and calibration expiration dates have been recorded in Para 9.2 .

The Missile Shield Enclosures grounding has been visually inspected and continuity tested.

The following instrumentation has been calibrated. Record the calibration expiration date:

Instrument No.

TSHL-06்23 $2 / 16 / 97$ $1 / 2 / 91$

Instrument No. TSHL -0624 Expiration Date $2+16 / 56$ Expiration Date $2 / 16 / 50$ 2/16/47?

The IE-0621 annunciator system in B1dg 241-AY-51 is functional.

For all steps that involve checking an annunciator on IE-0621 in Bidg 241-AY-51, the alarms shall be acknowledged and reset as necessary to complete the step.

The Receptacle and the HVAC circuit breakers, in B1dg 241-AY-51A; are open (OFF position).

The Receptacle and the HVAC circuit breakers, in Bldg 241-AY-51B, are apen (OFf position).

Circuit breakers AY102-PPI/\#5 and AY102-PP1/\#6, in the EES, are open (OFF. position).

Panelboard AY102-PPI is energized.

All worker safety equipment required to perform test is readily available. 
9.2 EQUIPMENT/INSTRUMENTS FOR TESTING OF SSS SUPPORT SYSTEMS

Supplied by Test Operator unless atherwise noted.

9.2.1 Volt-ohmmeters (VOM): $120 / 240$ to $277 / 480 \mathrm{~V}$ Instrument No. $0 / 6 \gamma$ Expiration Date $7 / 26 / 47$

\subsection{MEASUREMENTS - SSS SUPPORT SYSTEMS}

CAUTION: Observe proper electrical safety precautions around energized equipment in accordance with WHC-CM-1-10, WKS 15, Electrical Work Safety.

Note: Steps 9.3.1 through 9.3.7 involve testing the receptacle and the HVAC unit $(A C-0621)$, for Bldg 241-AY-51A.

9.3.1 Close the 241-AY-51A RCPT \& HVAC (AC-0621) feeder breaker AY102-PP1/\#6, in the EES (ON position).

$\frac{18 / 3 / 56}{48 / 3 / 16} 9.3 .2$

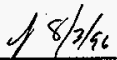

9.3 .4

$18 / 3 / 46$

\section{3 .5}

9.3 .6

$48 / 3 / 96$

9.3.6.1

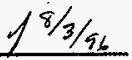

9.3.6.2

$18 / 3 / 56$

$9 \cdot 3 \cdot 6 \cdot 3$

$18 / 3 / \pi_{6} \quad 9.3 .6 .4$
Close the receptacle breaker, in BIdg 241-AY-51A (ON position).

Using the VOH, measure and verify the yoltage at the duplex receptacle, in Bidg 241-AY-51A, is in the range of 114 to $126 \mathrm{~V}$ ac. Verify that the GFCI feature of the duplex receptacle functions properly via the test and reset buttons. (After this step is completed, the receptacle is avallable for use).

Set the 81dg 241-AY-51A HVAC unit thermostat controls (TC-0826) to OFF.

Close the HWAC breaker in Bldg 241-AY-51A (ON position).

Verify that the BIdg 241-AY-51A HYAC unit functions properly by adjusting the thermostat controls (TC-0626) as follows:

Set the Bidg 241-AY-51A HVAC unit thermostat controls (TC-0626) to automatically maintain 50 to $70^{\circ} \mathrm{F}$. Set the thermostat controls (TC-0626) to operate in AUTO.

(In Auto or Manual) ecw- 4434 Raise the temperature settinglenough to cause the HVAC unit to start heating the inside of Bidg 24I-AY-51A and allow to run for approximately 5 minutes.

Lower the temperature setting enough to cause the HYAC unit to start cooling the inside of B BId 241-AY-51A and allow to run for approximately 5 minutes.

Set the Bidg 241-AY-51A HVAC unit thermostat controls (TC-0626) to maintain $50^{\circ}$ to $70^{\circ} \mathrm{F}$ in AUTO. 
9.3.7 Verify that the AY-FARM SEISHIC SYSTEM 241-AY-51A/B TEMP HIGH/LOW annuncfator window 2-3 on IE-062I functions properly, by performing the following in Bldg 241-AY-51A:

Lift a wire from the TSHL-0623 output terminals for high temperature and verify that the annunciator window is STEADY ON. Then reconnect the lifted wire and verify that the annunciator window is OFF.

9.3.7.2 Lift a wire from the TSHL-0623 output terminals for low temperature and verify that the annunciator window is STEADY ON. Then reconnect the lifted wire and verify that the annunciator window is OFF.

Note: Steps 9.3.8 through 9.3.14 involve testing the receptacle and the HVAC unit (AC-0622), for Bldg 241-AY-51B.

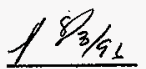

9.3 .8

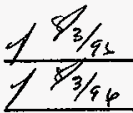

9.3 .9

$9.3 \cdot 10$

Close the 241-AY-518 RCPT \& HVAC (AC-0622) feeder breaker AY102-PP1/\#5, in the EES (ON position).

Close the receptacle breaker, in B1dg 241-AY-51B (ON position).

Using the VOM, measure and verify the voltage at the duplex receptacle, in BIdg 241-AY-51B, is in the range of 114 to $126 \mathrm{~V}$ ac. Verify that the GFCI feature of the duplex receptacle functions properly via the test and reset buttons. (After this step is completed, the receptacle is available for use).

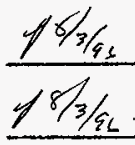

9.3 .11

Set the Bidg 241-AY-5IB HVAC unit thermostat controls (TC-0627) to OFF.

9.3.12 Close the HYAC breaker, in B1dg 241-AY-51B (ON position).

9.3.13 Verify that the B1dg 241-AY-51B HVAC unit functions properly by adjusting the thermostat controls $(T 6-0627)$ as follows:

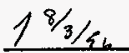

9.3 .13 .1

Set the Bldg 241-AY-51B HVAC unit thermostat controls (TC-0527) to automaticaliy maintain 50 to $70^{\circ} \mathrm{F}$. Set the thermostat controls (TC-0627) to operate in AUTO.

$\underline{78 / 3 / 96} 9.3 .13 .2$

(InAuto ormonel) $\cos \$ 431$

9.3.13.2 Raise the temperature setting/enough to cause the HVAC unit to start heating the inside of Bldg 241-AY-51B and allow to run for approximately 5 minutes.

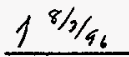

$9.3 \cdot 13.3$

Lower the temperature setting enough to cause the HVAC unit to start cooling the inside of Bldg 24I-AY-51B and allow to run for approximately 5 minutes.

$18 / 3 / 6$

$9.3 \cdot 13.4$

Set the Bldg 241-AY-518 HVAC unit thermostat controls (TC-0627) to maintain $50^{\circ}$ to $70^{\circ} \mathrm{F}$ in AUTO.

9.3.14 Verify that the AY-FARM SEISHIC SYSTEM 24I-AY-5IA/B TEMP HIGH/LOW annunciator window $2-3$ on IE-062I functions properiy, by performing the following in Bldg 241-AY-51B:

9.3.14.1 Lift a wire from the TSHL-0624 output terminals for high temperature and verify that the annunciator window is STEADY ON. Then reconnect the lifted wire and verify that the annunciator window is OFF. 
9.3.14.2 Lift a wire from the TSHL-0624 output terminals for low temperaiure and verify that the annunciator window is STEAOY ON. Then reconnect the lifted wire and verify that the annunciator window is OFF.

9.3.15 Perform the Final Equipment Lineup in step 9.4.

Upon completion of the testing steps in Section 9, the status of the equipment used in this test should be as shown in the following table. If any of the equipment is not in the required condition, notify the Test Director. The Test Director will determine the appropriate action.

\begin{tabular}{|c|c|c|c|}
\hline LOCATION & PERFORM/VERIFY & INITIAL & DATE \\
\hline EES & AY102-PP1/\#5: ON & 4 & $05 / 22 / 27$ \\
\hline EES & AY102-PPI/\#6: ON & 4 & $10 / 22 / 27$ \\
\hline $241-A Y-51 A$ & Receptacle breaker: ON & $\mathscr{H}$ & $(0 / 22 / 9)$ \\
\hline 241-AY-51A & HVAC breaker: ON & I & $15 / 22 / 47$ \\
\hline $241-A Y-51 A$ & HVAC unit thermostat controls (TC-0626): AUTO & 4 & $10 / 2 n / 47$ \\
\hline $241-A Y-51 A$ & Missile Shield Enclosure Doors: LOCKED CLOSED & $\not /$ & $6 / 22 / 47$ \\
\hline $241-A Y-51 B$ & Receptacle breaker: ON & 1 & $00 / 22 / 58$ \\
\hline $24 I-A Y-51 B$ & HVAC breaker: ON & $\mathscr{H}$ & $0 / 24 / 97$ \\
\hline $241-A Y-51 B$ & HVAC unit thermostat controls (TC-0627): AUTO & 4 & $(s / 22 / 97$ \\
\hline $241-A Y-51 B$ & Missile Shield Enclosure Doors: LOCKED CLOSED & 4 & $20 / 22 / 47$ \\
\hline $\begin{array}{l}241-\mathrm{AY}-51 \\
/ 1 \mathrm{E}-0621\end{array}$ & $\begin{array}{l}\text { AY-FARM SEISMIC SYSTEM 241-AY-5IA/B TEMP HIGH/LOH } \\
\text { annunciator window } 2-3: \text { OFF }\end{array}$ & $\mathscr{y}$ & $10 / 22 / 97$ \\
\hline
\end{tabular}


Note: If the results of any step do not agree with expectations, STOP the test and NOTIFY the Test Director.

10.1 PREREQUISITES FOR TESTING OF SSS AND MULTI PAK GROUP CONTROL PANEL

Note: This section of the ATP takes credit for the final functional testing of the SSSs by Nutherm International procedure TPS-7050, which is documented in the Vendor Information files. Therefore; the functionality of the temperature instruments for high ambient temperature (TSHH) will not be simulated or verified in this ATP. Additionally, this section of the ATP will not test the functionality of the Triaxial Seismic Detectors AY-0621 and AY-0622. The temperature instruments for high ambient temperature (TSHH) and the seismic detectors will be calibrated and tested by WHC procedure TF-FT-251-001, AY-Farm Seismic Shutdown Systen Functional Test.

The following conditions shall exist at start of this testing.

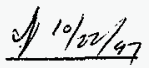

10.1 .1

of $10 / 2 \mathrm{w} / \mathrm{n}$

10.1 .2

$y^{10 / 20 / 53}$

10.1 .3

$110 / 22 / 97$

10.1 .4

$110 / 22 / 42$

10.1 .5

$\frac{110 / 22 / 42}{110 / 24 / 47}$

10.1 .6

10.1.7

$410 / 21 / 93$

10.1 .8

$110 / 22 / 92$

10.1 .9

$f^{15 / 22 / 41}$

10.1 .10

$10 / 22 / 92$

10.1 .11

HHC Project Engineer has been notified 24 hours prior to start of the testing.

Seismic Shutdown Systems AY-SSS-1A and AY-SSS-1B, and associated wiring, have been inspected for compliance with construction documents and general cleanitiness.

Reference documents (including this ATP) have been verified for correct revision number and outstanding ECNs.

A Prejob Safety Analysis has been prepared and a Prejob Safety Meeting has been conducted for this section of testing.

Test instruments have a valid calibration stamp attached. Test instrument identification numbers and calibration expiration dates have been recorded in Para 10.2 .

The SSS grounding has been visually inspected and continuity tested.

Seismic Shutdown System controls and indicators on IE-0621 in the EES have been installed.

Wiring from the AY-Farm Power Distribution Panel AY-POP-1 to Seismic Shutdown Systems AY-S5S-1A and AY-SSS-18 to the Multi-Pak Group Control panel has been continutty tested and meggered.

The EES Multi-Pak Group Control Panel circuit breakers have been continuity tested.

Al] circuit breakers on EES Multi-Pak Group Control Panel are open (OFF position).

The battery, inside each of the Seismic Shutdown System panels $A Y-S S S-1 A$ and $A Y-S S S-1 B$, has the battery terminal leads lifted from the battery terminals.

HNF $3 / 3198$

WHE-SD-W320-ATR-007

Rev 0

$04 / 15 / 96$ 
The pre-installation functional test been performed prior to site installation in accordance with the operating Instruction for Triaxial Seismic Trigger Model TS-33MOD. Record the performance date:

Instrument No. AE/ASH-0621 Date Performed $3 / 19 / 96$

Instrument No. AE/ASH-0522 Date Performed $3 / 19 / 96$

$10 / 22 / 9270.1 .13$

Note: For all steps that involve checking the annunciator on IE-0621 in the EES, the alarms shall be acknowledged and reset as necessary to complete the step.

$10 / 22 / 9710.1 .14$

$100 / 22 / 49$

$f^{10 / 22 / 43} 10.1 .16$

f $10 / 22 / 41 / 10.1 .17$

$y^{10 / 22 / 47} 10.1 .18$

$y^{10 / 22 / 47} 10.1 .19$

$4^{10 / 22 / 17}$

10.1 .20

$f^{10 / 22 / 4}>10.1 .21$

$f^{10 / 22 / 40710.1 .22}$
No wiring has been terminated on the load side of the feeder breakers on the Multi-Pak Group Control Panel, or the load side wiring is Iifted to prevent injury to personnel or damage to equipment.

The keys for operation of the AY-SSS-1A and AY-SSS-18 door interlock bypass switches are available.

A1l Multi-Pak Group Control Panel breakers are open (OFF position). mocours cria discoundit 5 wircit

The VSD input Gixctit beake on the VSD is open (OFF position). The wiring on the load side of the VSD input circutt breaker is lifted. 20409

The EES AY-EES-1 feeder breaker AY-POP-1/\#11 is open (OFF position).

$A Y-P D P-1$ is energized.

The HVAC in the Missile Shield Enclosure (AC-0621), B1dg 241-AY-51A, is operating.

The HVAC in the Missile Shield Enclosure $\{A C-0622\}, B 7 d g$ 241-AY-51B,

All worker safety equipment required to perform test is readily availabie. is operating.

10.2 EQUIPMENT/INSTRUMENTS FOR TESTING OF SSS AND MULTI-PAK GROUP CONTROL PANEL

Supplied by Test Operator unless otherwise noted.

10.2.1 Volt-ohmmeters (VOH): $120 / 240$ to $277 / 480 \mathrm{~V}$ CAC DATE $6 / 6 / 57$

Instrument No. $950-45-06-027$ Expiration Date $6 / 6 / 99$

10.2.2 Phase Rotation Meter: No ID number or calibration required.

10.3 CIRCUIT BREAKER SETTINGS FOR SSS AND MULTI-PAK GROUP CONTROL PANEL

If $1 \% 22 / 97$ 10.3.1 Verify that the SSS ISOLATION circuit breaker has a 600 A trip unit,

NOTE: The Seismic Trigger User Contact (between TB3-2 and TB3-3) cannot be checked by measuring continuity because it is a solid state relay. The Seismic Trigger sensors are reset by actuating the Trigger Sensor Reset Toggle Switch (HS-0633) [HS-0634] and then reset the User Contact by depressing the RESET pushbutton (HS-0631) [HS-0632]. 
$119 \% / 4)$

10.3 .2

$110 / 2 \% / 9110.3 .3$

$10 / 27 / 9210.3 .4$

y(10/3)/91 10.3 .5

$410 / 22 / 4)$

10.3 .6

$18 / 22 / 97$

10.3 .7
Verify that the SSS ISOLATION circuit breaker short-time delay pickup is set at $6 \times I_{n}$, in Bldg 241-AY-51A.

Verify that the SSS ISOLATION circuit breaker ground fault settings are set at $2\left(X I_{G}\right)$ and $I$ (instantaneous).

Verify that the PIT COOLER (R-0621) feeder breaker Multi-Pak Group Control Panel/ $\# Z_{3}$ has a $30 \mathrm{~A}$ trip rating.

Verify that the WINCH ( $W-0621$ ) feeder breaker MuIti-Pak Group Control Pane $1 / \# 1$ has a $7 \mathrm{~A}$ trip rating.

Verify that the IMMERSIBLE SLUICE PUMP (P-0621) feeder breaker Multi-Pak Group Control Panel/ $\# \beta_{2}$ has a $70 \mathrm{~A}$ trip rating.

Verify that the SPARE feeder breaker Multi-Pak Group Control Panel/\#4 443 has a 70 A trip rating.

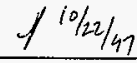

10.4 .1

$10 / 22 / 97$

10.4 .2

$10 / 22 / 97$

10.4 .3

$110 / 22 / 97$

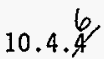

$-1$

$1 / 4 / 22 / 47$ $10.4 . \frac{7}{5}$

$110 / 22 / 4710.4 .8$ $110 / 22 / 9170.4 .7$

$\left.\right|^{10 / 22 / 47} \begin{aligned} & 10.4 .8 \\ & 10.4 .8 \%\end{aligned}$

MEASUREMENTS - SSS AND MULTI-PAK GROUP CONTROL PANEL

ME.4 MSUREMENTS - SSS AND MULTI-PAK GROUP CONTROL PANEL
CAUTION: $\begin{aligned} & \text { Observe proper electrical safety precautions around energized } \\ & \text { equipment in accordance with WHC-CM-1-10, WKS 15, Electrical Work } \\ & \text { Safety. }\end{aligned}$
Note: $\begin{aligned} & \text { Steps } 10.4 .1 \text { through } 10.4 .9 \text { involve testing and making connections } \\ & \text { that are necessary for the remainder of the ATP. }\end{aligned}$

ME.4 MSUREMENTS - SSS AND MULTI-PAK GROUP CONTROL PANEL
CAUTION: $\begin{aligned} & \text { Observe proper electrical safety precautions around energized } \\ & \text { equipment in accordance with WHC-CM-1-10, WKS 15, Electrical Work } \\ & \text { Safety. }\end{aligned}$
Note: $\begin{aligned} & \text { Steps } 10.4 .1 \text { through } 10.4 .9 \text { involve testing and making connections } \\ & \text { that are necessary for the remainder of the ATP. }\end{aligned}$

ME.4 MSUREMENTS - SSS AND MULTI-PAK GROUP CONTROL PANEL
CAUTION: $\begin{aligned} & \text { Observe proper electrical safety precautions around energized } \\ & \text { equipment in accordance with WHC-CM-1-10, WKS 15, Electrical Work } \\ & \text { Safety. }\end{aligned}$
Note: $\begin{aligned} & \text { Steps } 10.4 .1 \text { through } 10.4 .9 \text { involve testing and making connections } \\ & \text { that are necessary for the remainder of the ATP. }\end{aligned}$

ME.4 MSUREMENTS - SSS AND MULTI-PAK GROUP CONTROL PANEL
CAUTION: $\begin{aligned} & \text { Observe proper electrical safety precautions around energized } \\ & \text { equipment in accordance with WHC-CM-1-10, WKS 15, Electrical Work } \\ & \text { Safety. }\end{aligned}$
Note: $\begin{aligned} & \text { Steps } 10.4 .1 \text { through } 10.4 .9 \text { involve testing and making connections } \\ & \text { that are necessary for the remainder of the ATP. }\end{aligned}$

10.4 MEASUREMENTS - SSS AND MULTI-PAK GROUP CONTROL PANEL
CAUTION: $\begin{aligned} & \text { Observe proper electrical safety precautions around energized } \\ & \text { equipment in accordance with WHC-CM-1-10, WKS 15, Electrical Work } \\ & \text { Safety. }\end{aligned}$
Note: $\begin{aligned} & \text { Steps } 10.4 .1 \text { through } 10.4 .9 \text { involve testing and making connections } \\ & \text { that are necessary for the remainder of the ATP. }\end{aligned}$

Close the EES Bldg 241-AY-51 feeder breaker AY-PDP-1/\#11 (ON position).

Test the EES BTdg 241-AY-51 feeder breaker AY-PDP-1/\#11 trip function using the red test pushbutton on the trip unit.

$A X-P D P-1 / \not F / 1$

Reset and close the EES Bldg 241-AY-51 feeder breaker $A C C-N 1 / 3+$ (ON position).

Use the VOM to measure continuity between TB3-1 to TB3-2 (TSHH-06211 contact) to verify that the contact is closed in Bidg 241-AY-51A.

If the Seismic Trigger is not connected to the Seismic Shutdown System, 1 ift Teads to the Seismic Trigger from TB3-2 and TB3-3, install a \#12AWG jumper between TB3-2 and TB3-3, and then continue with remainder of Section 10 of this ATP."

Use the VOM to measure continuity between TB3-1 to TB3-2 (TSHH-06212 contact) to verify that the contact is closed in B7dg 241-AY-5IB.

If the Seismic Trigger is not connected to the Seismic Shutdown System, lift leads to the Seismic Trigger from TB3-2 and TB3-3, instali a \#12AWG jumper between TB3-2 and TB3-3, and then continue with remainder of Section 10 of this ATP."

Perform and verify the following on AY-SSS-1A in B7dg 241-AY-51A:

Connect the AY-SSS-1A battery terminaT leads that were lifted and tagged by vendor (wire $4-10$ connects to positive terminal and wire 4-11 connects to negative terminal) to the battery terminals. 
Using the VOM, measure the AY-SSS-1A battery voltage betweer. $T B 4-10(+)$ and $T B 4-11(-)$. Record the value of the AY-SSS-1A battery voltage on the Data Sheet.

if $10 / 22 / 9710.4 .10$

Verify that the AY-SSS-1A battery voltage in the preceding step is in

the range of 12.0 to $13.4 \mathrm{~V}$ dC.

Perform and verify the following on AY-SSS-1B in B1dg 24I-AY-51B:

Connect the AY-SSS-1B battery terminal leads that were Tifted and tagged by vendor (wire 4-10 connects to positive terminal and wire 4-11 connects to negative terminal) to the battery terminals.

1/ $12 / 22 / 9>10.4 .11$

Using the VOM, measure the AY-SSS-1B battery voltage between TB4-10(t) and TB4-11(-). Record the value of the AY-SSS-IB battery voltage on the Data Sheet.

Verify that the AY-SSS-1B battery voltage in the preceding step is in

the range of 12.0 to $13.4 \mathrm{~V}$ de. Steps 10.4.10 through 10.4.34 involve testing AY-SSS-1A, in Bidg 241-AY-51A.

Close the SSS ISOLATION breaker AY-SSS-CB in BIdg 241-AY-51A (ON position).

Test the SSS ISOLATION breaker trip function using the red test pushbutton on the trip unit, in Bldg 241-AY-51A, and verify that the breaker trips.

$10 / 22 / 9210.4 .12$

Reset and close the SSS ISOLATION breaker (ON position), in Bidg 241-AY-51A.

of $10 / 22 / 97210.4 .13$

Using the applicable key, piace the AY-SSS-IA door interlock key switch (HS-0629) to BYPASS in B1dg 241-AY-51A; the SSS cabinet door can now be opened without tripping the contactor (MI).

$110 / 22 / 5310.4 .14$

Using the VOM, measure and verify that all 3 phase-to-phase voltages on the 7 ine side of AY-SSS-1A contactor (MI) are in the range of 480 to $504 \mathrm{~V}$ ac in B1dg 241-AY-51A.

Y $10 / 22 / 47$

Verify that the AY-SSS-1A red TRIP light (YL-06211B) is ILLUNINATED and that the white SET light (YL-06210) is OFF in B1dg 241-AY-51A.

10/40.4.15 Verify the following at panel IE-0621 in B1dg 241-AY-51:

$1 \% / 22 / 9)$ 10.4.15.1 The Seismic Shutdown System red TRIP light (YL-06211A) is ILLUMINATED.

$10 / 2 / m)$

$110 / m \operatorname{lon}$

10.4.16.2 The AY-FARM SEISMIC SHUTDOWN SYSTEM TRIPPED annunciator window $1-3$ is. STEADY ON.

10.4.16.3 The AY-FARM SEISMIC SYS 241-AY-51A/B POWER FAILURE annunciator window 3-3 is STEADY ON.

W320007.ATP. 2558

HNF $8\left(\mathrm{~d}_{3}|3| 98\right.$

WHE-SD-W320-ATA-007

Rev 0

$04 / 15 / 96$ 
Using the YOM, measure and verify that all 3 phase-to-phase voltages on the load side of AY-SSS-1A contactor (MI) are $O V$ ac in Bldg 241-AY-51A.

$A^{(2 / 3) / 97} \quad 10.4 .18$

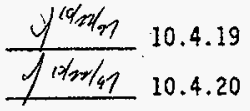

$y^{12 / 2 \% / 97} 10.4 .21$

$\$ 10 / 22 / 92 \quad 10.4 .22$

10.4.23 Verify the following at panel IE-0621 in Bidg 241-AY-51:

d $10 / 22 / 47$ 10.4.23.1 The Seismic Shutdown system red TRIP 1ight (YL-05211A) is ILLUMINATED.

$10 / 22 / 91$

10.4 .23 .2

$10 / 2 \% / 91$ The AY-FARM SEISHIC
remained STEACY ON
10.4 .23 .3

Y. $10 / 2 \% / 49$

10.4 .24

$1 \mathrm{co/22} / 9710.4 .25$

of cohves

10.4 .26

10.4 .27

ofothy

10.4 .27 .1

The AY-FARM SEISMIC SYS 241-AY-5IA/B POWER FAILURE annunciator window

3-3 is OFF.

Close the AY-SSS-1A cabinet door and place the AY-SSS-1A door.

interlock key switch (HS-0629) to NORMAL in Bldg 241-AY-51A.

Open the AY-SSS-1A cabinet door in B1dg 241-AY-51A; the contactor

(MI) should open.

Verify that the AY-SSS-IA red TRIP Iight (YL-06211B) and the white SET light (YL-06210) are both OFF in BTdg 241-AY-51A.

\section{ILUUAINAFEO.}

10.4.27.2 The AY-FARM SEISMIC SHUTOOWN SYSTEM TRIPPED annunciator window 1-3 remained STEADY ON.

$1 \mathrm{~m} / \mathrm{h} / \mathrm{an}$ 10.4.27.3 The AY-FARM SEISHI
$3-3$ is STEADY ON.

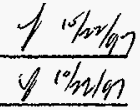

10.4 .28

Clase the AY-SSS-1A cabinet door in Bidg 24l-AY-5IA.

AND PLACE THE AY-S5S- IA DOOR INTaCoKK KEY

10.4 .29

Verify that the AY-SSS-1A red TRIP light (YL-06211B) is ILLUMINATED

and that the white SET light (YL-06210) is OFF in Bidg 241-AY-51A. 
10.4.30 Using the VOH, measure and verify that all 3 phase-to-phase voltages on the load side of AY-SSS-1A contactor (MI) are $O V$ ac in B1dg 241-AY-51A.

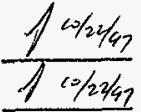

10.4 .31

10.4 .32

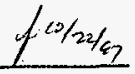

10.4 .33

Depress the AY-SSS-IA SET pushbutton (HS-06210) in B1dg 241-AY-51A.

Verify that the AY-SSS-1A white SET light (YL-06210) is ILLUMINATED. and that the red TRIP Tight (YL-06211B) is OFF in Bidg 241-AY-5IA.

Using the VOM, measure and verify that all 3 phase-to-phase voltages on the load side of AY-SSS-1A contactor (MI) are in the range of 480 to $504 \mathrm{~V}$ ac in Bldg 241-AY-51A.

10.4.34 Verify the following at panel IE-0521 in 81dg 241-AY-51:

of $(2 / 22 / 5)$

10.4.34.1 The Seismic Shutdown system red TRIP light (YL-06211A) is ILLUMINATED.

$100 / 2 y_{91}$

1 $10 / 22 / 97$

ILIUMINATED,

10.4.34.2 The AY-FARM SEISMIC SHUTDOWN SYSTEM TRIPPED annunciator window 1-3 remained STEADY ON.

10.4.34.3 The AY-FARM SEISMIC SYS 241-AY-51A/B POWER FAILURE annunciator window 3-3 is OFF.

Note: $\quad$ Steps 10.4.35 through 10.4.71 involve testing AY-SSS-1B in Bldg 241-AY-51B.

Ito/22/a) 10.4 .35

Using the applicable key, place the AY-SSS-1B door interlock key switch (HS-0530) to BYPASS in BIdg 241-AY-51B; the SSS cabinet door can now be opened without tripping the contactor (M2).

Ito/22/4, 10.4 .36

Using the VOM, measure and verify that all 3 phase-to-phase voltages on the line side of $A Y-S S S-1 B$ contactor (M2) are in the range of 480 to $504 \mathrm{~V}$ ac in B.1dg $241-A Y-51 B$.

$d 10 / 22 / 4210.4 .37$

Verify that the AY-SSS-1B red TRIP light (YL-06213) is ILLUMINATED and that the white SET light (YL-06212) is OFF in B1dg 241-AY-51B.

of $8 / 22 / 9710.4 .38$

Using the VOM, measure and verify that all 3 phase-to-phase voltages on the load side of AY-SSS-1B contactor (M2) are $O V$ ac in

B1dg 24I-AY-51B.

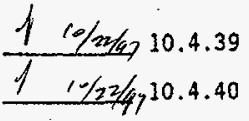

Depress the AY-SSS-1B SET pushbutton (HS-06212) in B1dg 241-AY-51B.

Verify that the AY-SSS-1B white SET light (YL-06212) is ILLUMINATED and that the red TRIP light $(Y L-06213)$ is OFF in BIdg 241-AY-5IB.

10.4.41 Verify the following at panel IE-0621 in 81dg 241-AY-51:

1 10/2y/a) 10.4.41.1 The Seismic Shutdown System red TRIP light (YL-06211A) is OFF.

I(0/22/8)

10.4.41.2 The AY-FARM SEISMIC SHUTDOWN SYSTEM TRIPPED annunciator window $1-3$ is OFF.

of $10 \% 22 \%$ ? 10.4.41.3 The AY-FARM SEISMIC SYS 241-AY-51A/B POWER FAILURE annunciator window 3-3 remained OFF.

HNF $\mathrm{gQS}_{3 / 3} / 98$

HE-SD-W320-ATR-007

Rev 0

04/15/96 
Using the yoM, measure and verify that all 3 pirase-to-phase voltages on the load side of AY-SSS-1B contactor (M2) are in the range of 480 to $504 \mathrm{~V}$ ac in Blig 241-AY-518.

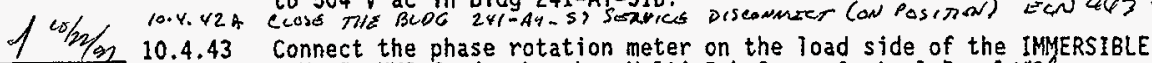

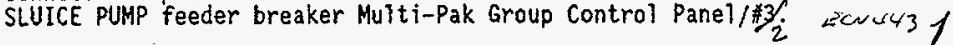

of $6 / 22 / 1210.4 .44$

Close the IMMERSIBLE SIUICE PUMP feeder breaker Multi-Pak Group Control Panel/\#Z2(ON posjtion).

$160 / 22 / 9210.4 .45$ ecr cur 7

Using the phase rotation meter, verify that the phase rotation is clockwise (for $A, B, C$ ).

$100 / 22 / 2) 10.4 .46$

Using the VOM, measure all 3 phase-to-phase voltages on the load side of the IMHERSIBLE SLUICE PUMP feeder breaker MUTti-PaK Group Control

$1 / 2 / 22 / 97,10.4 .47$ Panel/\#3. 2 Record the values of $V_{A B}, V_{B C}$, and $V_{C A}$ on the Data Sheet. $60 \mathrm{~N} 443$ of

Verify that the voltages in the preceding step are in the range of 480 to 504 y ac.

$10 / 22 / 9710.4 .48$

Close the AY-SSS-1B cabinet door and place the AY-SSS-1B door interlock key switch (HS-0630) to MORMAL in Bidg 241-AY-51B.

$105 / 22 / 9210.4 .49$

Open the AY-SSS-1B cabinet door in BIdg $24 I-A Y-518$; the contactor (M2) should open.

$10 / 22 / 9710.4 .50$

Verify that the AY-SSS-1B red TRIP light (YL-06213) and the white SET light (YL-06212) are both OFF in BIdg 241-AY-51B.

$10 / 22 / 92$

10.4.51 Verify the following at panel IE-062l in B1dg 241-AY-51:

$10 / 22 / 01$

10.4.51.1 The Seismic Shutdown System red TRIP light (YL-06211A) is off IH HUMINAFEO.

10.4.51.2 The AY-FARM SEISMIC SHUTDOWN SYSTEM TRIPPED annunciator window 1-3 is STEADY ON.

10.4.51.3 The AY-FARM SEISMIC SYS 241-AY-5IA/B POWER FAILURE annuncjator window 3-3 is STEAOY ON.

$110 / 22 / 97$

10.4.52 Close the AY-SSS-1B cabinet door in BIdg 241-AY-51B.

$10 / 22 / 91$

10.4 .53

Verify that the AY-SSS-1B red TRIP light (YL-06213) is ILLUMINATED. and that the white SET light (YL-06212) is OFF in BIdg 241-AY-51B.

10.4.54 Verify the following at panel IE-0621 in BIdg 241-AY-51:

o $10 / 22 / 97$

10.4.54.I The Seismic Shutdown System red TRIP light (YL-06211A) is ILLUMINATED.

$110 / 22 / 42$

Yo/2y/97

10.4.54.2 The AY-FARM SEISMIC SHUTDOWN SYSTEM TRIPPED annunciator window 1-3 remained STEADY ON.

10.4.54.3 The AY-FARM SEISMIC SYS 24I-AY-5IA/B POWER FAILURE annunciator window. 3-3 is OfF.

W320007.ATP.2558 


\section{$\cos \csc 1$}

$1 / 0 / \mathrm{m}_{9} / 9$ 10.4.55 Using the VOM, measure and verify that all 3 phase-to-piase valtages on the load side of the IMMERSIBLE SLUICE PUMP feeder breaker Multi-Pak Group Control Panel/ $\$ Z_{2}$ are $0 \mathrm{~V}$ ac.

$\frac{110 / 22 / 97}{110 / 22 / 97} 10.4 .56$

Depress the AY-SSS-1B SET pustibutton (HS-06212) in B1dg 241-AY-51B.

Verify that the AY-SSS-18 white SET light (YL-06212) is ILLUMINATED and that the red TRIP light (YL-06213) is OFF in BIdg 241-AY-51B.

10.4.58 Verify the following at panel IE-0621 in BIdg 241-AY-51:

$f(x / 2 x / 5 y$

10.4.58.1 The Seismic Shutdown System red TRIP light (YL-06211A) is OFF.

$100 / 2 / 91$

10.4.58.2 The AY-FARM SEISMIC SHUTOOWN SYSTEM TRIPPED annunciator window 1-3 is OFF.

$16 \% / 2 / 91$ 10.4.58.3 The AY-FARM SEISHIC SYS 24I-AY-51A/B POWER FAILURE annunciator window 3-3 remained OFF.

$110 / 22 / 97 / 10.4 .59$

Using the VOM, measure and verify that all 3 phase-to-phase voltages on the load side of the IMMERSIBLE SLUICE PUMP feeder breaker

\begin{tabular}{l}
$\frac{f(0 / 22 / 97}{10.4 .60}$ \\
$10 / 22 / 97$ \\
\hline
\end{tabular} Multi-Pak Group control Panel/HZ3 are in the range of 480 to $504 \mathrm{~V}$ ac. Depress the AY-SSS-1B TRIP pushbutton (HS-06213) in 81dg 241-AY-51B.

Verify that the AY-SSS-1B red TRIP light (YL-06213) is ILLUMINATED and that the white SET 1ight (YL-05212) is OFF in Bldg 241-AY-518.

10.4.62 Verify the following at panel IE-0621 in Bldg 241-AY-51:

of $00 / 22 / 97$ 10.4.62.1 The Seismic Shutdown System red TRIP light (YL-06211A) is ILLUMINATED.

1) $10 / 22 / 97$ 10.4.62.2 The AY-FARM SEISMIC SHUTDOWN SYSTEM TRIPPED annunciator window $1-3$ is STEADY ON.

of $c 0 / 22 / 9210.4 .62 .3$ The AY-FARM SEISMIC SYS 241-AY-51A/B POWER FAILURE annunciator window 3-3 remained OFF.

d $00 / 22 / 97 \times 0.4 .63$

flo/22/91 10.4 .54

$40 / 22 / 97 \cdot 10.4 .65$

$f^{10 / 22 / 97} 10.4 .66$
$f^{(0 / 22 / 9)} 10.4 .67$

$4.21 / 91$
Using the voH, measure and verffy that all 3 phase-to-phase voltages on the load side of the IMMERSIBLE SLUICE PUMP feeder breaker MuTti-Pak Group Control Pane]/ $\# Z_{2}$ are $0 \mathrm{~V}$ ac.

Open the IMMERSIBLE SLUICE PUMP feeder breaker MUTti-Pak. Group Control Panel/\#z/2(OFF position).

Disconnect and remove the phase rotation meter.

Depress the AY-SSS-IB SET pushbutton (HS-06212) in BIdg 241-AY-51B.

Verify that the AY-SSS-1B white SET light (YL-06212) is ILLUMINATED and that the red TRIP 1 ight $(Y 1-06213)$ is OFF in BIdg $241-A Y-51 B$.

10.4.68 Verify the following at panel IE-0621 in BIdg 241-AY-51:

10.4.68.1 The Seismic Shutdown System red TRIP light (YL-062IIA) is OFF.

W320007.ATP. 2558 
10.4.68.2 The AY-FARM SEISMIC SHUTDOWN SYSTEM TRIPPED annunciator window $1-3$ is OFF.

$1 / 0 / 22 / 43$ 10.4.68.3 The AY-FARM SEISMIC SYS 241-AY-51A/B POWER FAILURE annunciator window

$1 \frac{10 / 2 / 102}{10}$

10.4 .69

$1^{10 / 21 / 97}$

10.4 .70

$110 / 22 / 91$

10.4 .71

Note:

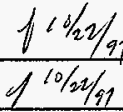

10.4 .72

10.4 .73

$10 / 22 / 11$

10.4 .74

3-3 remained OFF.

Close the IN-LINE SLUICE BOOSTER PUMP VSD LAS DISCONACT SWITCA (ON position).

Using the VOM, measure all 3 phase-to-phase voltages on the load side of the IN-LINE SLUICE BOOSTER PUMP feeder on the VSO. Record the values of $V_{A B}, V_{B C}$, and $V_{C A}$ on the Data Sheet. Ymolos cass piscownser swirch Verify that the voltages in the preceding step are in the range of
480 to $504 \mathrm{~V}$ ac.

\section{Steps 10.4 .72 through 10.4 .82 involve additional testing of both} $A Y-S S S-1 A$ and $A Y-S S S-1 B$, in BIdgs. 241-AY-51A and 241-AY-51B respectively.

Depress the AY-SSS-1A TRIP pushbutton (HS-06211B) in B1dg 241-AY-51A.

Verify that the AY-SSS-IA red TRIP light (YL-062118) is ILLUMINATED and that the white SET light (YL-06210) is OFF in BIdg 241-AY-51A.

Verify that the AY-SSS-1B red TRIP light (YL-06213) and the white SET light ( $\mathrm{YL}-06212)$ are both OFF in Bldg $241-A Y-51 B$.

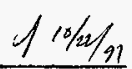

10.4 .75

Verify the following at pane1 IE-0621 in Bldg 241-AY-5I:

10.4.75.1 The Seismic Shutdown System red TRIP light (YL-06211A) is ILLUMINATEO.

$10 / 2 / 91$

10.4.75.2 The AY-FARM SEISMIC SHUTDOWN SYSTEM TRIPPED annunciator window $1-3$ is STEADY ON.

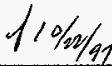

$110 / 21 / 91$

10.4.75.3

10.4 .76

$\frac{110 / 22 / 97}{100 / 22 / 91}$

10.4 .77

10.4 .78

10.4 .79

10.4 .80

10.4 .8

The AY-FARM SEISMIC SYS 241-AY-5IA/B POWER FAILURE annunciator window 3-3 is STEADY ON.

Using the vom, measure and verify that all 3 phase-to-phase voltages on the load side of the IN-LINE SLUICE BOOSTER PUMP YSD input-breaker on the VSD are $0 \mathrm{~V}$ ac.

Depress the AY-SSS-1A SET pushbutton (HS-06210) in Bldg 241-AY-51A.

Verify that the AY-SSS-1A white SET light (YL-06210) is ILLUMINATED and that the red TRIP light (YL-062118) is OFF in BTdg 241-AY-51A.

Depress the AY-SSS-1B SET pushbutton (HS-06212) in BIdg 241-AY-51B.

Verify that the AY-SSS-1B white SET light (YL-05212) is IELUMINATED and that the red TRIP light (YL-06213) is OFF in BIdg 241-AY-518.

Verify the following at panel IE-0621 in 81dg 241-AY-5I:

/10 10.4.81.1 The Seismic Shutdown System red TRIP light (YL-C621IA) is OFF.

W320007.ATP. 2558

HNF $\mathrm{ged}_{3 / 3198}$

HHE-SD-W320-ATR-007

Rev 0

$04 / 15 / 96$ 
10.4.81.2 The AY-FARM SEISMIC SHUTDOWN SYSTEM TRIPPED annunciator window $1-3$ is OFF.

$410 / 22 / 97$ 10.4.81.3 The AY-FARM SEISMIC SYS 241-AY-51A/B POWER FAILURE annunctator Window $10 / 22 / 91$ 3-3 is OFF.

10.4.82 Using the VOH, measure and verify that all 3 phase-to-phase voltages on the load side of the IN-LINE SLUICE BOOSTER PUNP VSD thput-breakere switch on the VSD are in the range of 480 to $504 \mathrm{~V}$ ac. molded case disconnect ECN 409

Note: Steps 10.4 .83 through 10.4 .94 involve testing the remote trip feature $10 / 22 / 27$ 10.4 .83 of the Seismic Shutdown System from panel IE-062I in Bldg 241-AY-51.

Depress the remote Seismic Shutdown system TRIP pushbutton (HS-0621IA) on pane1 IE-0621 in Bldg 241-AY-51.

$10 / 22 / 92$

10.4.84 Verify the following at panel IE-0621 in BIdg 241-AY-51:

10.4.84.1 The Selsmic Shutdown System red TRIP light (YL-06211A) is ILLUMINATED.

$1 / 0 / 22 / 47$ $010 / 22 / 97$ $110 \% 22 / 9210.4 .85$ $10 / 22 / 97$ $410 / 22 / 97$ 10.4 .86 10.4.84.2 The AY-FARM SEISMIC SHUTDOWN SYSTEM TRIPPEO annunciator window $1-3$ is STEADY ON.

10.4.84.3 The AY-FARM SEISMIC SYS 241-AY-51A/B POWER FAILURE annunciator window 3-3 is STEAOY ON.

Verify that the AY-SSS-1A red TRIP Iight (YL-05211B) is ILLUMINATED and that the white SET light $(\mathrm{YL}-06210)$ is OFF in BIdg 24I-AY-51A.

Verify that the AY-SSS-18 red TRIP T1ght (YL-06213) and the white SEY light (YL-05212) are both Off in Bldg $241-A Y-5 ! B$.

10.4.87 Using the VOM, measure and verffy that all 3 phase-to-phase voltages ed $N_{409}$ on the load side of the IN-LINE SLUICE BOOSTER PUNP VSD AnPut breakeren

switchn the VSO are OV $V$ ac.

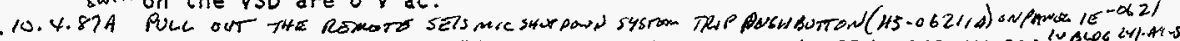
10.4.88 Depress the AY-SSS-IA SET pushoutton (HS-06210) in B1dg 241-AY-51A.

10.4.89 Verify that the AY-SSS-1A white SET 1ight (YL-05210) is ILLUAINATEO and that the red TRIP light (YL-OEZ1IB) is OFF in Bidg $241-A Y-51 A$.

$\frac{f^{10 / 22 / 97} 10.4 .90}{10 / 22 / 97} 10.4 .91$ Depress the AY-SSS-1B SET pushbutton (HS-06212) in B1dg 241-AY-51B.

Verify that the AY-SSS-1B white SET ilght (YL-06212) is ILLUMINATED and that the red TRIP light (YL-06213) is OFF in BIdg $241-A Y-518$.

10.4.92 Verify the following at panel IE-0621 in Bldg 241-AY-5I:

$\frac{y^{10 / 22 / 47}}{100 / 22 / 57}$ 10.4.92.1 The Selsmic Shutoown system red TRIP light (YL-O6211A) is OrF.

10.4.92.2 The AY-FARM SEISMIC SHUTDOWN SYSTEM TRIPPED annunctator window 1-3 is OFF.

10/2\%/9) 10.4.92.3 The AY-FARM SEISMIC SYS 241-AY-51A/B POWER FAILURE annunCiator WindOw 3-3 is OFF.

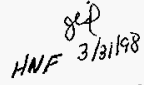

HE-SD-W320-ATR-007 
Using the VOM, measure and verify that all 3 phase-to-phase voitages on the load side of the IN-LINE SLUICE BOOSTER PUMP VSD input breaker

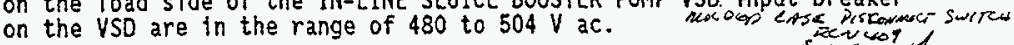
Open the IN-LINE SLUICE BOOSTER PUMP VSD inptut breaker on the VSD (OFF position).

Note: Steps 10.4.95 through 10.4.104 involve testing the AY-SSS-1A Battery Charger JC-1381 and AY-SSS-18 Battery Charger JC-0622.

$10 / 22 / 4210.4 .95$

Place the AY-SSS-1A door interlock key switch (HS-0629) to BYPASS in Bidg 241-AY-51A.

$10 / 22 / 97 \cdot 10.4 .96$

$10 / 22 / 57 \quad 10.4 .97$

Using the VOM, measure and verify that the voltage between AY-SSS-1A $T B 3-4$ and $T B 3-5, j$ s in the range of 120 to $126 \mathrm{~V}$ ac in

Bldg 241-AY-5IA. 20N b6/ 114

Using the VOM, measure the AY-SSS-IA Battery Charger JC-062I output voltage between AY-SSS-1A TB4-10 $(+)$ and TB4-11(-) in 81dg 241-AY-51A. Record the value of the AY-SSS-1A Battery Charger JC-062l output

$110 \%$ Excepiont $z$ voltage on the Data Sheet.

Verify that the AY-SSS-1A Battery Charger $U C$-0521 output voltage in the preceding step is in the range of 13.5 to $14.0 \mathrm{~V} \mathrm{dc}$.

of $10 / 2 x / 97,10.4 .99$

Close the AY-SSS-1A cabinet door and place the AY-SSS-1A door. interlock key switch (HS-0629) to NORMAL in Bldg 241-AY-51A.

of $0 / 22 / 51,10.4 .100$ $400 / 22 / 9710.4 .101$

Place the AY-SSS-1B door interlock key switch (HS-0630) to BYPASS in Bldg 241-AY-518.

Using the YOM, measure and verify that the voltage between AY-SSS-18 $T B 3-A / /$ and $T B 3-5 / 2$ is in the range of 120 to $126 \mathrm{~V}$ ac in Bidg 241-AY-51B. एटN $66 /$ ff

$015 / 2 \pm / 4720.4 .102$

Using the YOM, measure the AY-SSS-1B Battery Charger JC-0622 output voltage between AY-SSS-1B TB4-10 $(+)$ and $T B 4-11(-)$ in B1dg $241-A Y-51 B$. Record the value of the AY-SSS-IB Battery Charger JC-0622 output Exeosisontzz
$10 / 22 / 9210.4 .103$ voltage on the Data Sheet.

Verify that the AY-SSS-1B Battery Charger JC-0622 output voltage in the preceding step is in the range of 13.5 to $14.0 \mathrm{~V} d c$.

$f^{10 / 22 / 47} 10.4 .104$

Close the AY-SSS-1B cabinet door and place the AY-SSS-1B door interlock key switch (HS-0630) to NORMAL in BIdg 241-AY-51B.

Y $10 / 22 / 57$ 10.4.105

$110 / 22 / 47$

10.4 .106

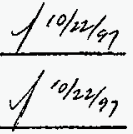

10.4 .107

10.4 .108 10.4 .108 ill
Remove the $A Y-S S S-1 A$ and $A Y-S S S-1 B$ door interlock keys.

Reconnect any wiring that was lifted from the load side of the $480 \mathrm{~V}$ feeder breakers on EES Multi-Pak Group Control Panel, due to this procedure.

Reconnect the wiring that was lifted from the load side of the VSD input breaker on the VSO, due to this procedure.

then $10.4 \% 110$, see page $30 a$ \& 306 .

Perform the Fina? Equipment Lineup in step 10.5. f $11 / 4 / 47^{10.4 .112}$ $\int \in e^{661}$
Operate the Immersible Sluice Pump, the In-Line Sluice Booster Pump and the winch in accordance with procedure HNF-SD-W320-PROC-001. Verify that both Seismic Shutdown Systems (with the seismic triggers fully functional) AY-SSS-1A and AY-SSS-1B, in 241-AY-51A and $241-A Y-51 B$ respectively, do NOT trip. 


\section{Description of Change}

a. Para. 10.4.4 through 10.4.9.3; Renumber steps as shown on attached pages.

b. para. 10.4.7 (after kenumbering): Add text to end of paragraph as folldws: "If

this step cannot be completed suckessfully, 1 ift leads to the Seismic trigger
unit from TB3-2 and TB3-3, instal1 $312 A W G$ fumper between TB3-2 and TB3-3, and then continue with remainder of Section 10 of this ATP."

c. Para. 10,4.9 (after renumbering): Revise text from "... Bldg 241-AY-51A ..." ta "... BIdg 241-AY-51B ...". Add text to end of paragraph as follows: "If this step cannot be completed successfully, lift leads to the sejsmic Trigger unit from TB3-2 and TB3-3, instaTh $a$ \#12AWG jumper between TB3-2 and TB3-3, and then confinue with remainder of Section 10 of this ATP."

d. Para. 10.4.108: Renumber this paragraph to be "10.4.111" and add new paragraphs as fellows:

10.4.108 If a jumper was installed in step 10.4.7, perform and verify the following; if not, then skip this step:

NA $10 / 2 / 2 / 510.4 .108 .1$

Depress the AY-SSS-1A TRIP pushbutton (HS-06211B) in Bldg 241-AY-51A.

AS $/ 1 / 22 / 8,10.4 .108 .2$ 0pen the SSS ISOLATION breaker AY-SSS-CB in BIdg 241-AY-5IA (OFF position).

NA $/ 4 / 21 / 9710.4 .108 .3$

Remove jumper between TB3-2 and TB3-3, and reconnect the Seismic trigger unit leads that were lifted on AY-SSS-1A in Bldg 241-AY-51A.

NAt $f^{2} / 2 x / 5$,

10.4.108.4 Reset the Seismic Trigger sensors by actuating the Trigger Sensor Reset Toggle Switch (HS-0633) and reset the User Contact by depressing the AY-SSS-1A RESET pushbutton (HS-0631)."

10.4.109 If a jumper was installed in step 10.4.9, perform and verify the following; if not, then skip this step:

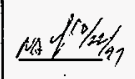

10.4.109.1

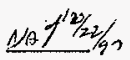

10.4 .109 .2 $N a y^{2} \% 2 / 27$

10.4 .109 .3
Depress the AY-SSS-1A TRIP pushbutton (HS-06211B) in B]dg 241-AY-51A, if necessary.

Open the SSS ISOLATION breaker AY-SSS-CB in BIdg 241-AY-51A (OFF position), if necessary.

Remove jumper between TB3-2 and TB3-3, and reconnect the Seismic trigger unit leads that were lifted on AY-SSS-1B in

B1dg 241-AY-51B. 


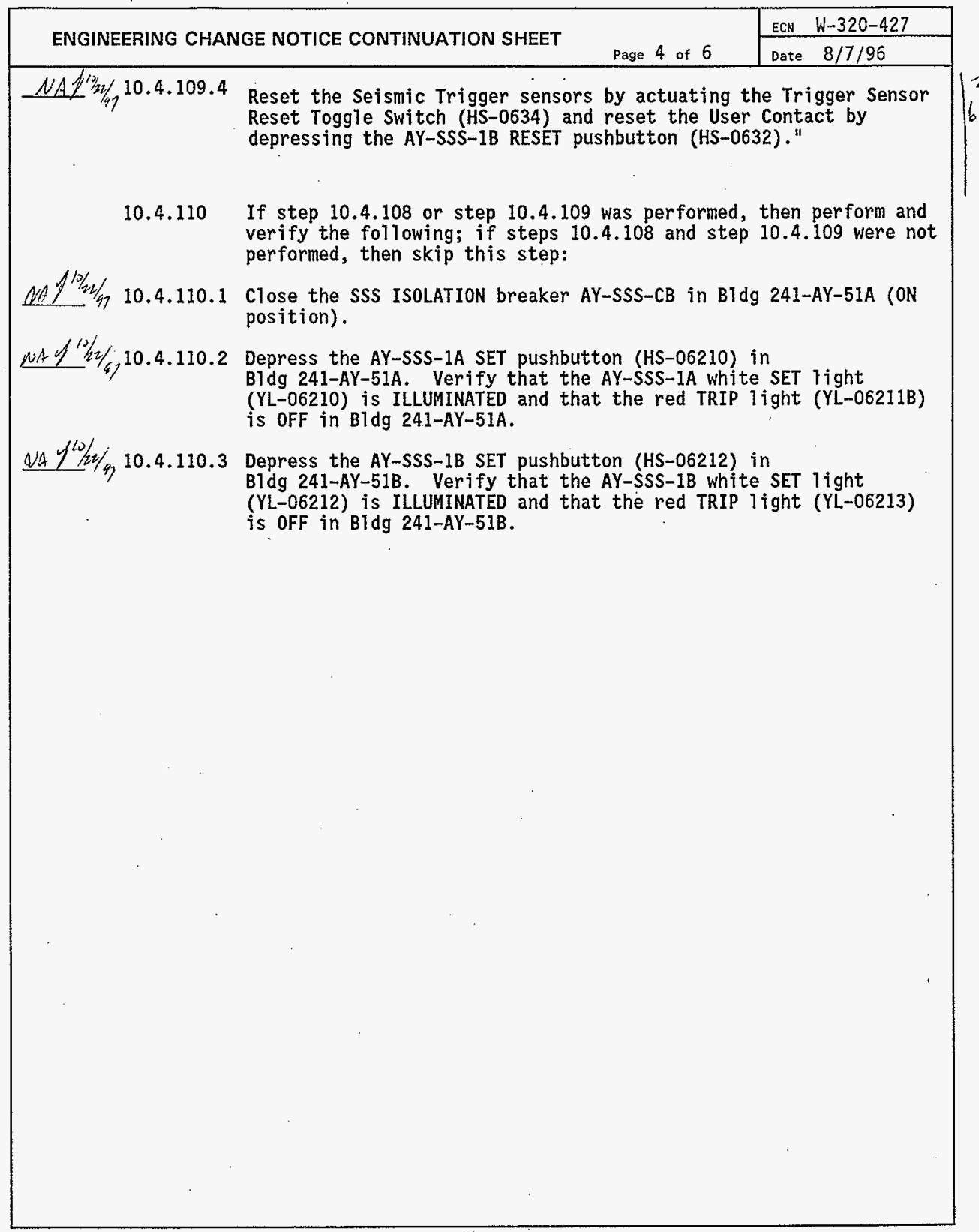




\begin{tabular}{|c|c|c|c|c|}
\hline \multicolumn{5}{|c|}{ SECTION 10 DATA SHEET WHC-SD-W320-ATP-007 } \\
\hline STEP & PERFORM/YERIFY & MEASUREMENT & INITIAL & DATE \\
\hline 10.4 .8 .2 & $\begin{array}{l}\text { AY-SSS-1A TBA-10(+) to TB4-11(-) } \\
\text { (battery): } \text { VOM } V \mathrm{dc}=\end{array}$ & 12.9 volts dc & 1 & $\log _{22}(9)$ \\
\hline 10.4 .9 .2 & $\begin{array}{l}\text { AY-SSS-1B TB4-10(t) to TB4-11(-) } \\
\text { (battery): VOM } \vee \mathrm{dc}=\end{array}$ & 12.8 Volts dc & y & $10 / 22 / 57$ \\
\hline \multirow{3}{*}{10.4 .46} & $\begin{array}{l}\text { Multi-Pak Group Control Panel/ } / \# \text { : } \\
\text { VOM } V_{A B}=\end{array}$ & 469. Voits & \multirow{3}{*}{ f } & \multirow{3}{*}{$8 / 15 / 40$} \\
\hline & $\begin{array}{l}\text { Multi-Pak Group Control Panel/ } / \pi_{2}: \\
\text { VOM } V_{B C}=\end{array}$ & $469 \quad$ Volts & & \\
\hline & $\begin{array}{l}\text { Multi-Pak Group Controi Panel/\#3: } \\
\text { VOM } V_{\mathrm{CA}}=\end{array}$ & 466 volts & & \\
\hline \multirow{3}{*}{10.4 .70} & 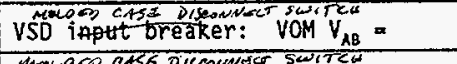 & 464 Voits & \multirow{3}{*}{$y$} & \multirow{3}{*}{$8 / 15 / / 6$} \\
\hline & 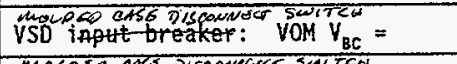 & $464 \quad$ volts & & \\
\hline & 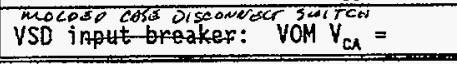 & $456 \quad$ Volts & & \\
\hline 10.4 .97 & $\begin{array}{l}\text { AY-SSS-IA TBA-10(+) to TB4-11(-) } \\
\text { (battery charger JC-0621 output): } \\
\text { VOM } V \text { dc }=\end{array}$ & 13.2 Voits de & $\mathscr{H}$ & $10 / 22 / 97$ \\
\hline 10.4 .102 & $\begin{array}{l}\text { AY-SSS-1B TB4-10(+) to TB4-11(-) } \\
\text { (battery charger JC-0622 output): } \\
\text { voM } v \text { dc = }\end{array}$ & 13.1 Voits de & 4 & $10 / 22 / 47$ \\
\hline
\end{tabular}


10.5 FINAL EQUIPMENT LINEUP FOR TESTING OF SSS AND MULTI-PAK GROUP CONTROL PANE:-

Upon completion of the testing steps in Section 9, the status of the equipment used in this test should be as shown in the following table. If any of the equipment is not in the required condition, notify the Test Director. The Test Director will determine the appropriate action.

\begin{tabular}{|c|c|c|c|}
\hline & SECTION 10 FINAL EQUTPKENT LINEUP WHC-SD-N320-ATP- & 007 & \\
\hline LOCATION & PERFORM/VERIFY & INITIAL & DATE \\
\hline EES & 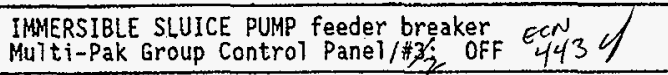 & 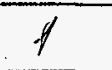 & $10 / 22 / 47$ \\
\hline EES & $\begin{array}{l}\text { IN-LINE SLUICE BOOSTER PUMP VSO input-breaker } \\
\text { (on the YSD): OFF }\end{array}$ & teat & $10 / 22 / 47$ \\
\hline EES & $\begin{array}{l}\text { EES BIdg 241-AY-51 feeder breaker } \\
\text { AY-PDP-1/\#11: ON }\end{array}$ & & $10 / 22 / 47$ \\
\hline EES & SSS ISOLATION breaker: ON & & $10 / 22 / 41$ \\
\hline $241-A Y-51 A$ & $\begin{array}{l}\text { Door Interlock Key Switch (HS-0629): NORMAL \& } \\
\text { KEY REMOVED }\end{array}$ & & $10 / 22 / 47$ \\
\hline $241-A Y-51 A$ & TRIP light $(Y L-06211 B):$ OFF & d & $10 / 22 / 92$ \\
\hline $241-A Y-51 A$ & SET light $(\mathrm{YL}-06210):$ ON & 4 & $10 / 22 / 42$ \\
\hline $241-A Y-51 A$ & HVAC unit (AC-0621): OPERATING IN AUTO & & $10 / 22 / 47$ \\
\hline $241-A Y-51 A$ & Hissile Shield Enclosure Doors: LOCKED CLOSED & & $10 / 22 / 47$ \\
\hline $241-A Y-51 B$ & $\begin{array}{l}\text { Door Interlock Key Switch (HS-0630): NORMAL \& } \\
\text { KEY REMOVED }\end{array}$ & & $10 / 22 / 97$ \\
\hline $241-A Y-53 B$ & TRIP light $(Y L-06213):$ OFF & & $10 / 22 / 47$ \\
\hline $241-A Y-51 B$ & SET light $(Y L-05212):$ ON & & $10 / 22 / 42$ \\
\hline $241-A \gamma-51 B$ & HVAC unit (AC-0622): OPERATING IN AUTO & & $10 / 22 / 47$ \\
\hline $241-A Y-518$ & Missile Shield Enclosure Doors: LOCKED CLOSED & & $10 / 22 / 92$ \\
\hline $\begin{array}{l}241-A Y-51 \\
/ I E-0621\end{array}$ & SSS TRIP light (YL-0621IA): OFF & & $10 / 22 / 47$ \\
\hline $\begin{array}{l}241-A Y-51 \\
/ I E-0621\end{array}$ & $\begin{array}{l}\text { AY-FARM SEISMIC SHUTOOWN SYSTEM TRIPPED } \\
\text { annunciator window } 1-3: \text { OFF }\end{array}$ & & $10 / 22 / 97$ \\
\hline $\begin{array}{l}241-A Y-51 \\
\text { IIE-0621 }\end{array}$ & $\begin{array}{l}\text { AY-FARM SEISMIC SYS } 241-A Y-51 A / B \text { POWER FAILURE } \\
\text { annunciator windoH } 3-3: \text { OFF }\end{array}$ & & $10 / 22 / 97$ \\
\hline $\begin{array}{l}241-A Y-51 \\
/ I E-0621\end{array}$ & $\begin{array}{l}\text { AY-FARM SEISMIC SYSTEM 241-AY-5IA/B TEMP HIGH/LOH } \\
\text { annunciator window 3-4: OFF }\end{array}$ & $\mathcal{M}$ & $10 / 2249$ \\
\hline
\end{tabular}

$\gg$ END OF SECTION $10 \ll$

W320007.ATP. 2558 


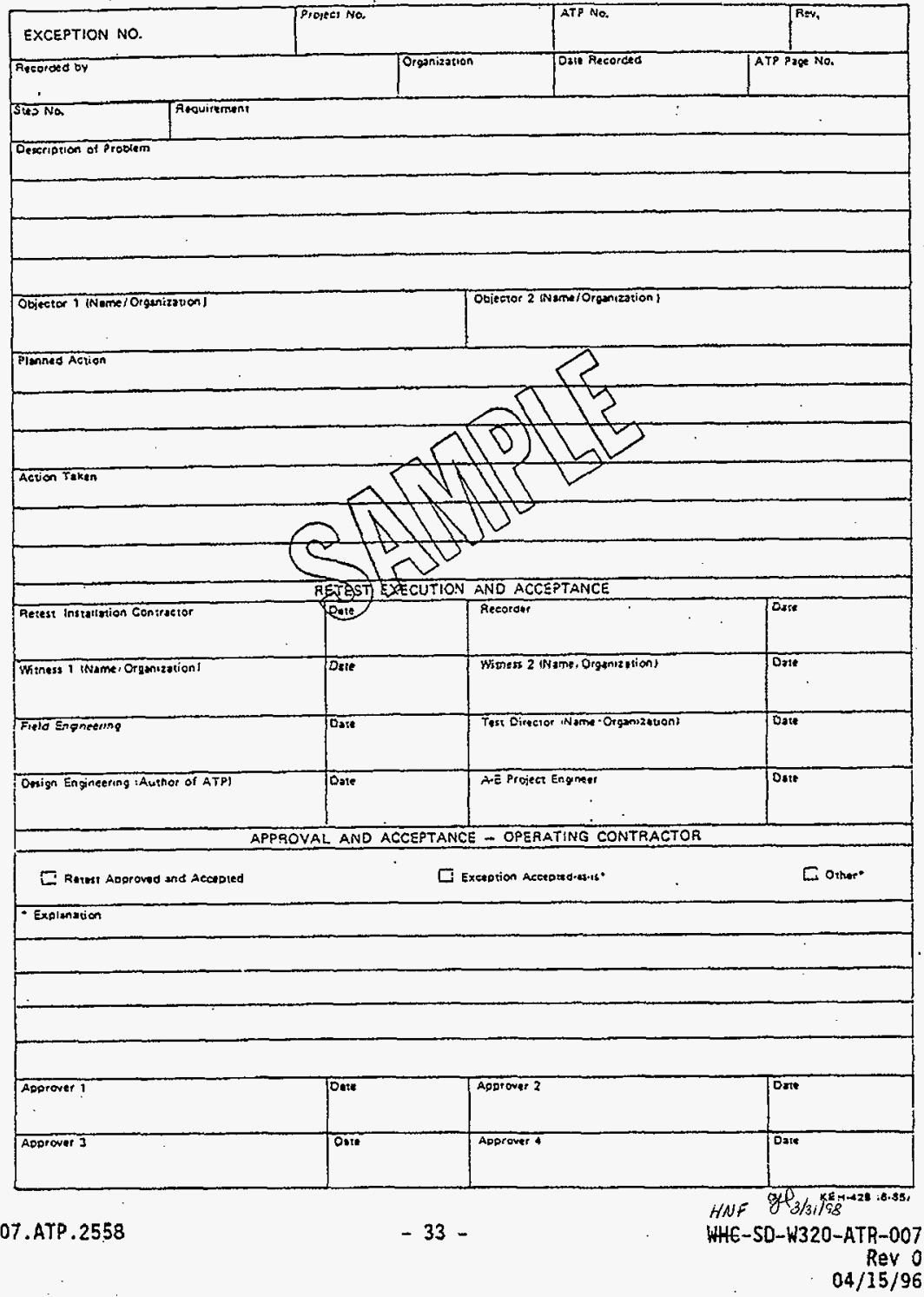




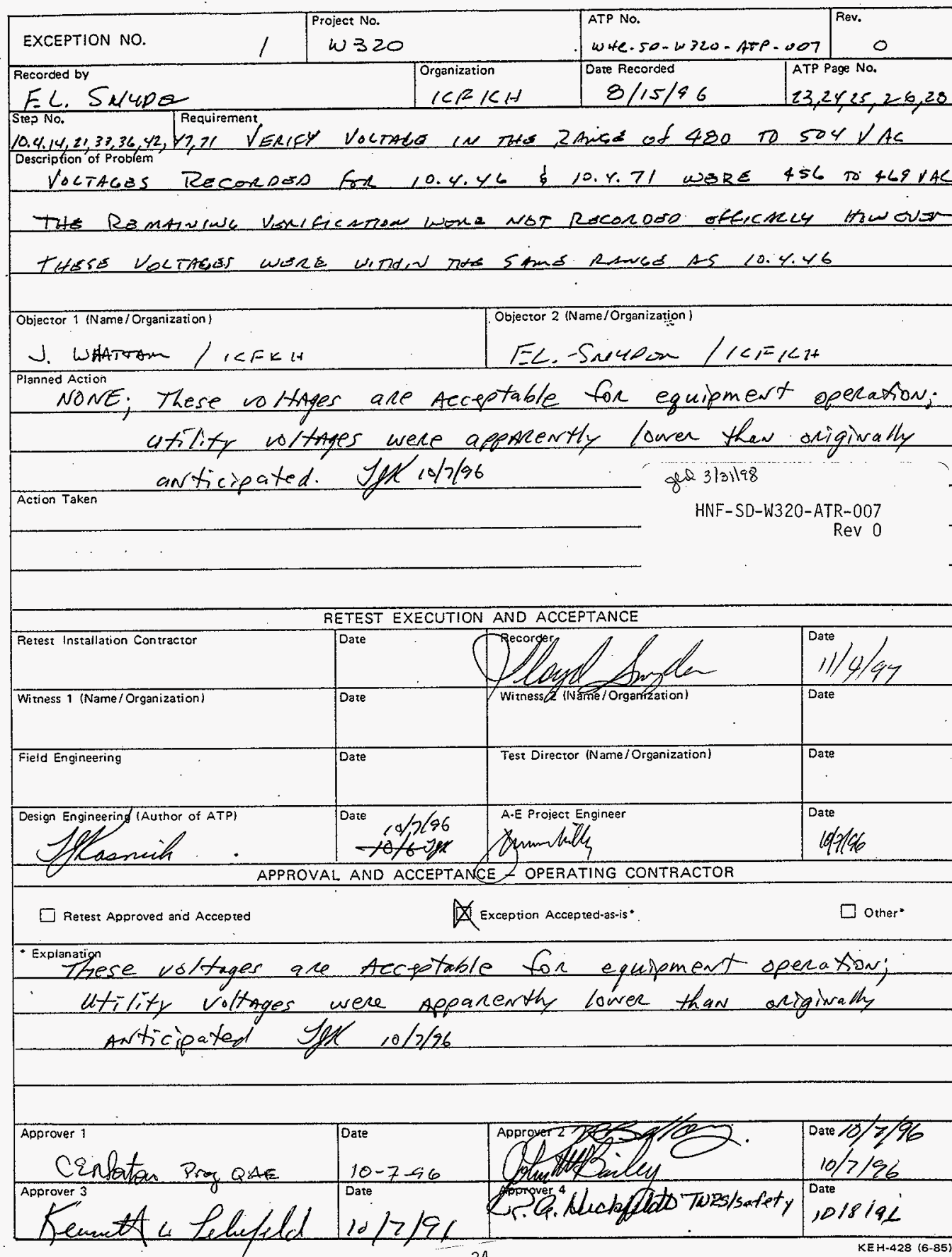




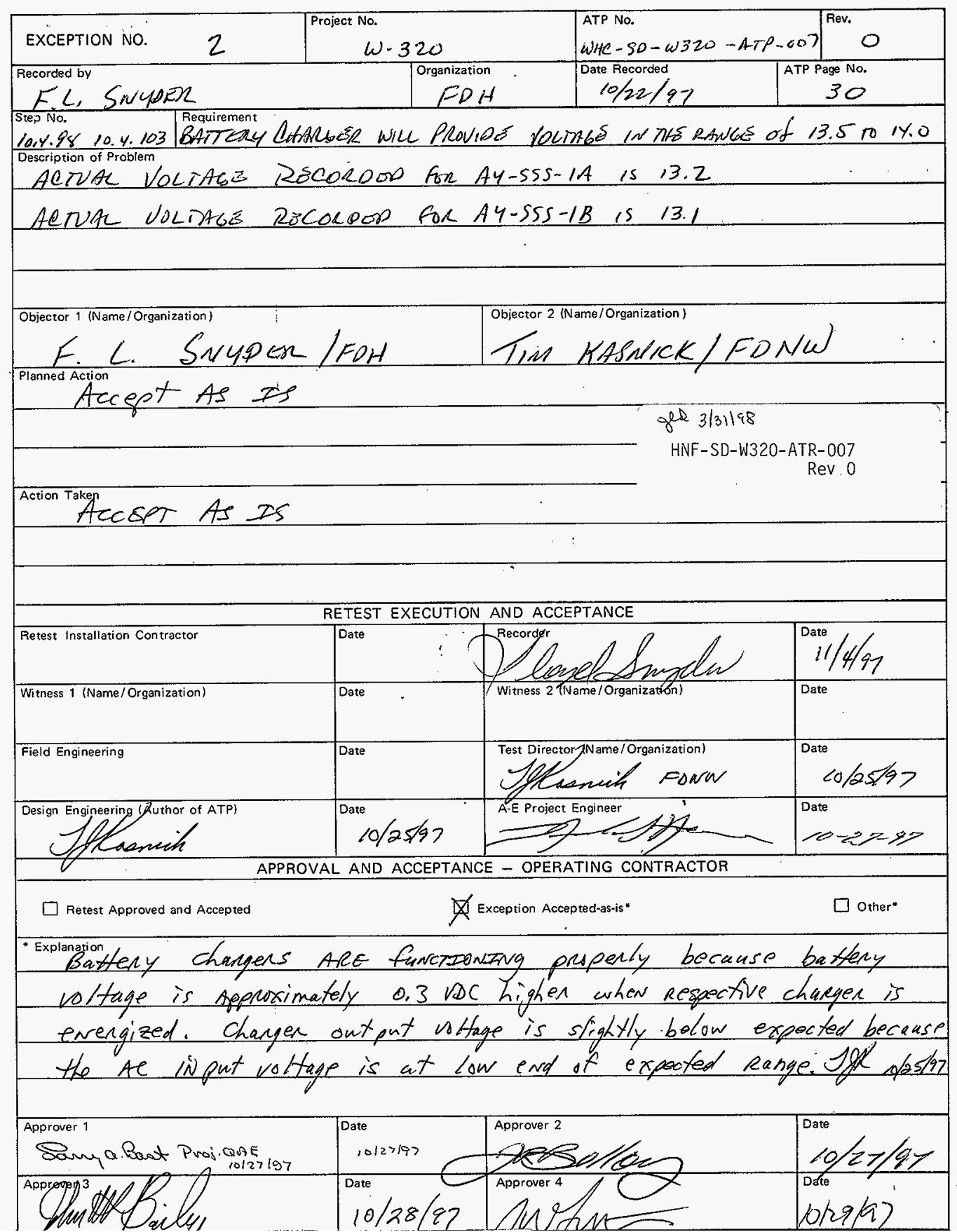




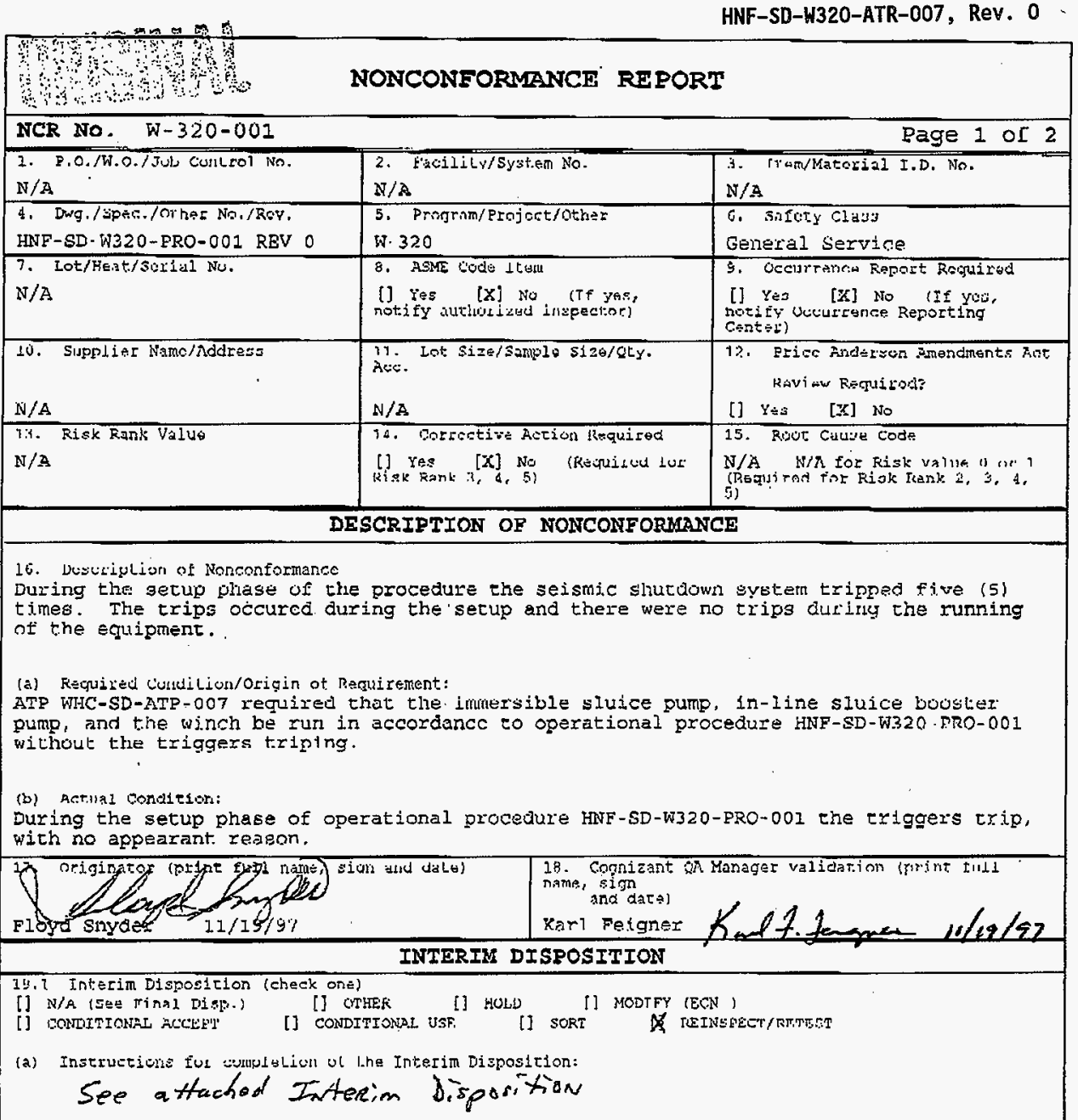




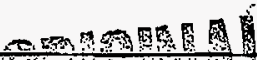

ती

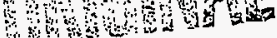

NONCONFORMENCE REPORT

NCR NO. W-320-001

एँge 2 of 2

\section{INTERIM DISPOSITION APRROVALS}

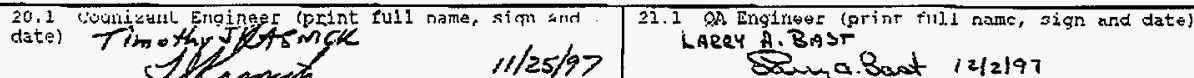

\subsection{Aulinerifed Inspect}

see

E10:-k 0

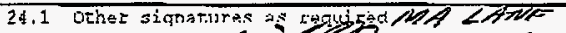

forg. Date

\section{COMPLETION OF INTERIN DISPOSITION}

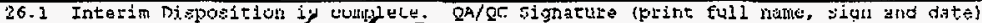

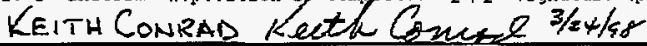

\section{FINAL DISPOSITION}

$19 . \hat{z}$ Final Disposition
[) tJSE-hS-IS
[] Kヒㄴㄷ"1"
M REFATR
[] FENOKK

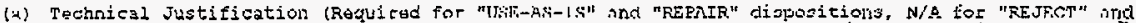

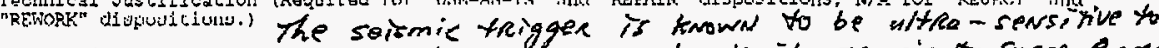

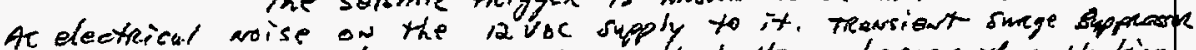
is wecessary to blook weise on isput ts bathery chatien thus blocking Noise from reuching cherger output lavac) to teigger.

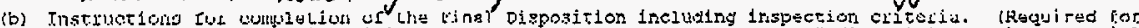

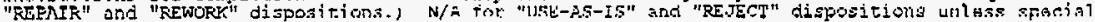
mor rnlf axe nesced.

N/A

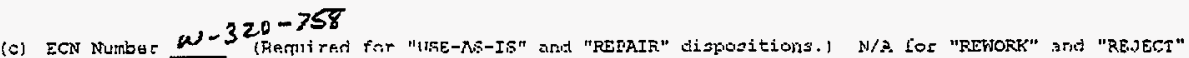
liupesiliens.

(i) Snrrontivo hetiong (actiona to prevent fecurronce) when raquired, sse Bloek 1a.

$$
\text { Nf } A
$$

\section{FINAL DISPOSITION APRROVALS}

\begin{tabular}{|c|c|}
\hline 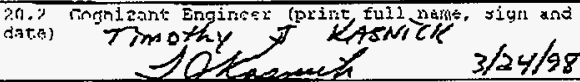 & 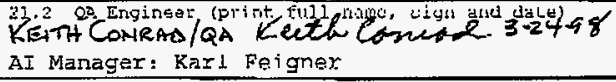 \\
\hline 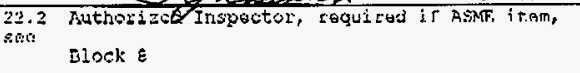 & 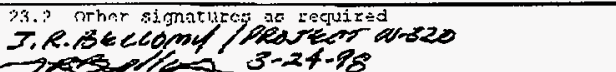 \\
\hline 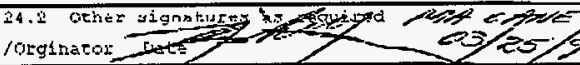 & 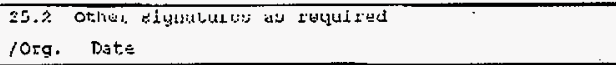 \\
\hline
\end{tabular}
25.2 Pcoopt
[] K Kuj:L
(1) Folion on NCR
Qn/gr rloches print ful\} mame, yign and date 


\section{MCR \#H-320-001 Interim Disposition Evaluate AY-Farm AY-SSS-1A Spurious Trips}

Prepared by TJ Kasnick $11 / 20 / 37$

Background: On 11/4/97, maintenance procedure HNF-SD-W320-PROC-001 (which operates the winch, Immersible Sluice Pump, and In-Line Sluice Booster Pump) was being performed. Both Seismic Shutdown System (SSS) cabinets at AY-Farm were initially tripped and therefore the two SSS cabinets were SET in order for power to be avajlable for operation of the motors. A short time after the two AY-Farm SSS cabinets were SET, they tripped; this occurred about 5 times before the cabinets remained SET; the Missile Shield Enclosure (B)dg 241-AY-51A) HYAC unit appeared to be a possible source of vibration and was de-energized. The maintentance procedure was then conducted without any problems. After the maintenance procedure was completed, the HVAC unit was restarted and the SSS remained SET for about 15 minutes; it was noted later that the SSS in cabinet $A$ was again spuriously tripping; it was also noted that soi] compaction work was going on inside the AY-Farm fence about $100 \mathrm{ft}$ away. This purpose of this evaluation is to determine if the AY-Farm SSS is functioning correctly and what may causing the spurious trips.

1. Verify that the shielding enclosure box surrounding the seismic trigger is firmly anchored to the concrete pad.

Verified:

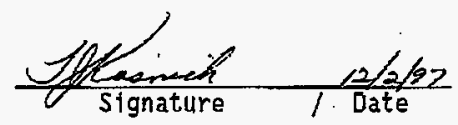

2. Verify that the seismic trigger is properiy anchored to the concrete pad in accordance with the vendor instructions.

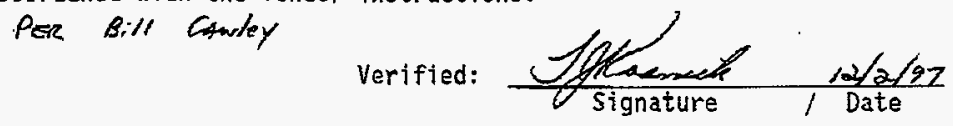

3. Check that the calibration of the seismic trigger in AY-SSS-1A is correct.

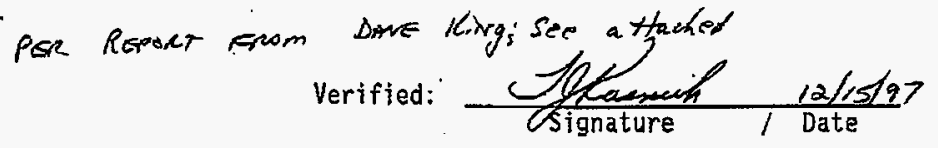




\section{Evaluate AY-Farm AY-SSS-1A Spurious Trips}

4. Verify that the filter in the missile shield atr conditioning unjt is clean and that the unit is functioning correctly. (this step can be performed at anytime; does NOT need to be performed in sequence with any other steps).

Verified:

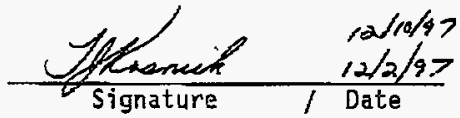

5. Verify that the battery charger is functioning properly (i.e. battery charger output voltage is approximately 0.3 Vdc greater than battery voltage when charger is off). (this step can be performed at anytime; does NOT need to be performed in sequence with any other steps).

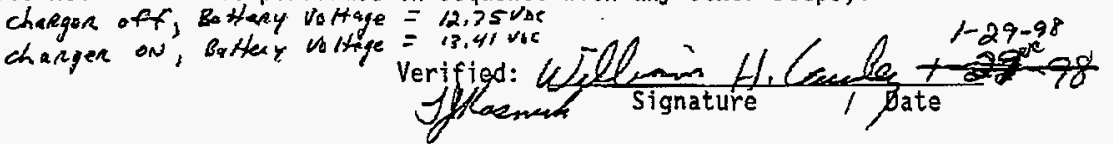

6. If the previous steps do not yield a cause for the spurious tripping and the spurious tripping still persists, connect a test instrument that will record possible noise Tevels on the $12 \mathrm{Vdc}$ supply voltage to the seismic trigger; connect the test instrument at terminals TB4-10(t) and TB4-11(-). Note observations.

If there is excessive noise on the $12 \mathrm{Vdc}$ supply to the seismic trigger, connect a test instrument that will record possible noise levels on the 120 Vac supply to the battery charger. Note observations.
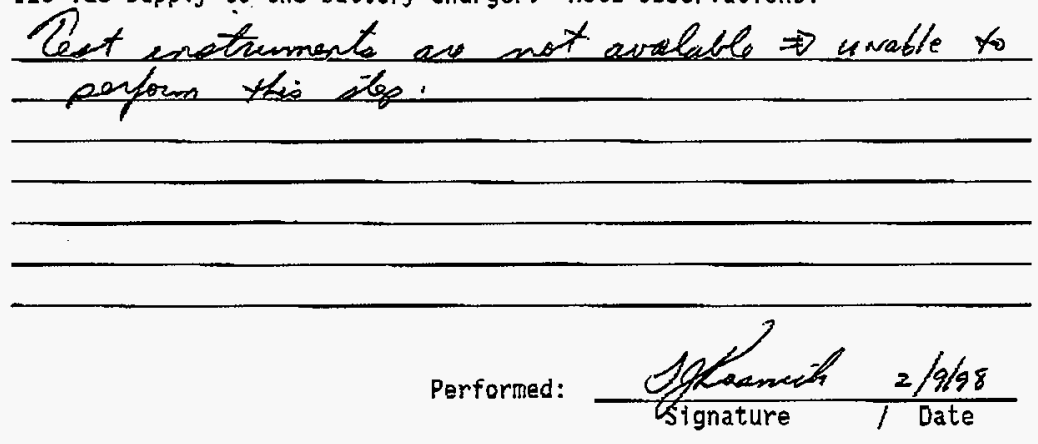


\begin{tabular}{lllll}
\hline $04 / 01 / 98$ & $10: 35 \quad$ TITLE III/AI & & T7006 \\
\hline & & & \\
& & HNF-SD-W320-ATR-007, ReV. 0
\end{tabular}

Evaluate AY-Farm AY-SSS-IA Spurious Trips

7. If the previous steps do not yield a cause for the spurious tripping and the spurious tripping still persists, install an accelerometer type test instrument next to the seismic trigger shielding enclosure that will measure and record vibrations that are present. Note observations.

Accelerometer wot available; therefore the s to not portorned

Performed:

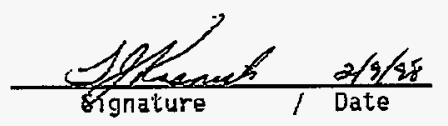

Comment's :

Due to exhume sensitivity terectrite purchased

transient whoop supnesur to probot battery charger input from vase spits. Device ivotalfel ended. ECN w-320-75\%; installation completed an 3/ular. As of $3 / 2 y / 28$ lo :00 Am, no tribes have occuritef sine installation of surge suppressor.

Page 3 of 3

Filename: AYTR|P.NCR

40 


\section{NCR \#W-320-001 Interim DIsposition Iroubleshooting of AY-Farm AY-SSS-1A Spurious Trips}

Troubleshooting history for Seismic Shutdown System AY-SSS-1A (10cated in Bldg 241-AY-51A)

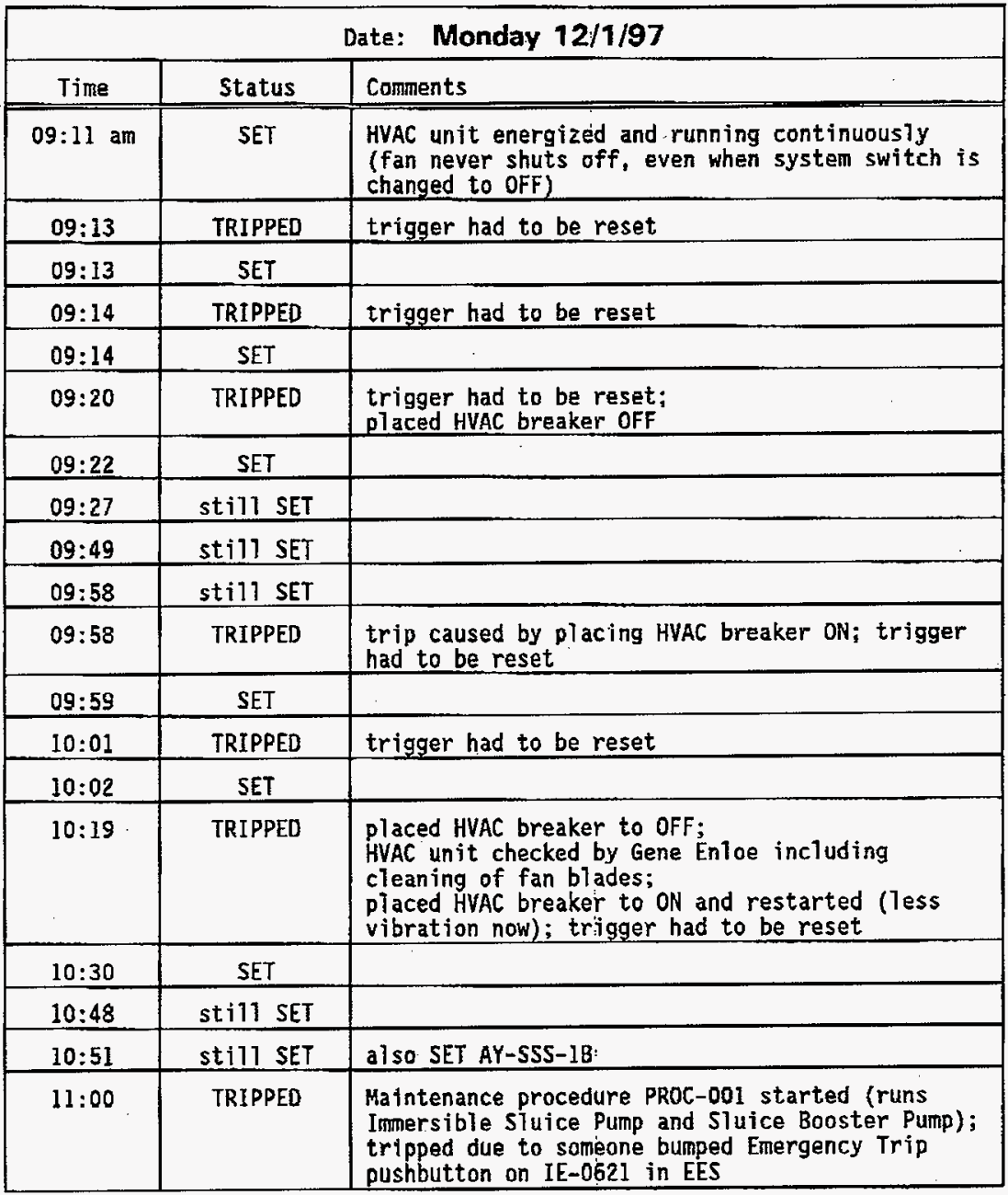


NCR \#W-320-001_Interim Disposition

Troubleshooting of AY-Farm AY-SSS-1A Spurious Trips (Continued)

\begin{tabular}{|c|c|c|}
\hline \multicolumn{3}{|r|}{ Date: Monday $12 / 1 / 97$} \\
\hline Time & Status & Comments \\
\hline $11: 01$ & SET & al SO SET AY-SSS-1B \\
\hline $11: 04$ & TRIPPED & $\begin{array}{l}\text { Placed } H V A C \text { breaker to OFF; trigger had to be } \\
\text { reset on } 1 \mathrm{~A} \text {, but not for } 1 \mathrm{~B} \text {. }\end{array}$ \\
\hline $11: 04$ & SET & also SET AY-SSS-1B \\
\hline $11: 16$ & still SET & \\
\hline $11: 33$ & still SET & maintenance procedure completed \\
\hline $12: 30 \mathrm{pm}$ & still SET & \\
\hline $12: 55$ & TRIPPED & 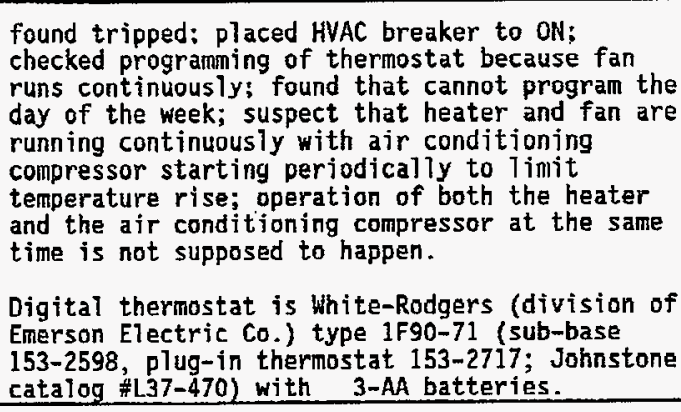 \\
\hline$-1: 30$ & & $\begin{array}{l}\text { temperature inside Bldg } 241-A Y-51 A \text { was about } \\
80^{\circ} \mathrm{F} \text {, well above heating setpoint of } 70^{\circ} \mathrm{F} \text { and } \\
\text { cooling setpoint of } 75^{\circ} \mathrm{F} \text {. Verified program } \\
\text { setpoints. }\end{array}$ \\
\hline$-2: 30$ & & $\begin{array}{l}\text { temperature inside Bldg } 241-A \gamma-51 \mathrm{~A} \text { is } 73^{\circ} \mathrm{F} \text {, } \\
\text { which is in normal range. }\end{array}$ \\
\hline
\end{tabular}


HNF-SD-W320-ATR-007, Rev. 0

NCR \#H-320-001 Interim Disposition Troubleshooting of AY-Farm AY-S5S-1A Spurious Trips (Continued)

\begin{tabular}{|c|c|c|}
\hline \multicolumn{3}{|r|}{ Date: Tuesday 12/2/97 } \\
\hline Time & Status & Comments \\
\hline $7: 00$ am & & $\begin{array}{l}\text { Called Digital thermostat vendor (White-Rodgers) } \\
\text { and discussed problems with thermostat and that } \\
\text { fan is rumning continuousiy, even when system } \\
\text { switch changed to ofF. } \\
\text { Vendor recommended to remove batteries for } 15 \\
\text { minutes to allow thermostat to reset, and then } \\
\text { re-install batteries and reprogram. If this } \\
\text { does not solve problem, vendor recommended } \\
\text { replacing the thermostat. }\end{array}$ \\
\hline 9:30 & & $\begin{array}{l}\text { Met with Gene Enloe at AY-Farm and discussed } \\
\text { thermostat and HVAC unit operation. Checked } \\
\text { HYAC unit and discovered that heater and atr } \\
\text { conditioning comppressor were both runntng } \\
\text { (contactors were both closed), which is not } \\
\text { normal. } \\
\text { Pulled Bldg } 241-A Y-51 A \text { thermostat out of sub- } \\
\text { base and removed batteries. } \\
\text { Also pulled Bldg } 241-A Y-51 B \text { thermostat, checked } \\
\text { programming (and verified can set day of week) } \\
\text { and installed it in Bldg 24l-AY-51A; Bldg } 241- \\
\text { AY-51A HVAC unit performed properly, 1.e. fan } \\
\text { did not run continuously. }\end{array}$ \\
\hline$-9: 45$ & & $\begin{array}{l}\text { Re-installed batteries in the Bldg 241-AY-51A } \\
\text { thernostat and reprogrammed; still cannot } \\
\text { program day of week. } \\
\text { Pulled Bldg } 241-A Y-51 B \text { thermostat that was } \\
\text { temporily installed in B1dg 241-AY-51A and re- } \\
\text { installed it in Bidg } 241-A Y-51 B ; B 1 \text { dg } 241-A Y-51 B \\
\text { HVAC unit performs properly. } \\
\text { Re-installed the Bldg } 241-A Y-51 A \text { thermostat and } \\
\text { HVAC unit fan operation appears to be normal } \\
\text { now. }\end{array}$ \\
\hline $10: 20$ & SET & $\begin{array}{l}\text { Bldg } 241-A Y-51 A \text { HVAC unit appears to be } \\
\text { operating normally. }\end{array}$ \\
\hline $10: 21$ & still SET & $\begin{array}{l}\text { Using thermostat keypad controls, operated Bldg } \\
\text { 24l-AY-51A HVAC unit through two cooling cycles } \\
\text { and two heating cycles; sSS did not trip. }\end{array}$ \\
\hline
\end{tabular}


NCR \#W-320-001 Interim Disposition

Troubleshooting of AY-Farm AY-SSS-1A Spurious Trips (Continued)

\begin{tabular}{|c|c|c|}
\hline \multicolumn{3}{|r|}{ Date: Tuesday $12 / 2 / 97$} \\
\hline Time & Status & Comments \\
\hline $10: 58$ & still SET & \\
\hline $11: 18$ & StIIl SET & $\begin{array}{l}\text { Using thermostat keypad controis, operated B7dg } \\
\text { 241-AY-51A HVAC unit through two cooling cycles } \\
\text { and two heating cycles; SSS did not trip. }\end{array}$ \\
\hline $12: 13$ & still SET & \\
\hline $12: 14$ & still SET & a) So SET AY-SSS-IB \\
\hline $12: 49$ & still SET & AY-SSS-1B also Still SET \\
\hline $12: 54$ & still SET & AY-SSS-1B also still SET \\
\hline 1:09 pm & sti11 SET & AY-SSS-1B also still SET \\
\hline$\sim 2: 00$ & still SET & $\begin{array}{l}\text { AY-5SS-1B al so stt11 SET; } \\
\text { per Bill Cawley }\end{array}$ \\
\hline$-3: 00$ & TRIPPED & per Bill Cawley \\
\hline & & PAR prepared to buy replacement thermostat \\
\hline
\end{tabular}


NCR \#H-320-001 Interim Disposition

Troubleshooting of AY-Farm AY-S55-1A Spurious Irips (Continued)

\begin{tabular}{|c|c|l|}
\hline \multicolumn{2}{|c|}{ Date: Wednesday 12/10/97 } \\
\hline Time & Status & Comments \\
\hline \%10:00 am & $\begin{array}{l}\text { Installed replacement digital thermostat (White- } \\
\text { Rodgers) Operated unit through heat cycle, air } \\
\text { conditioning cycle, and manualiy started fan, } \\
\text { but no Seismic Shutdown System trips occurred. } \\
\text { BTdg 241-AY-51A HWAC unit appears to be } \\
\text { operating normally. }\end{array}$ \\
\hline
\end{tabular}

\begin{tabular}{|c|c|c|}
\hline \multicolumn{3}{|c|}{ Dates: Friday $12 / 12 / 97$ - Wednesday $12 / 17 / 97$} \\
\hline Time & Status & Comments \\
\hline $\begin{array}{l}12 / 12 / 97 \\
\text { through } \\
12 / 15 / 97\end{array}$ & . & $\begin{array}{l}\text { Seismic Shutdown System AY-SS-1A trigger was } \\
\text { calibration checked in the Instrumentation shop } \\
\text { on } 12 / 12 \text { and found to be out of calibration; } \\
\text { trigger was recalibrated. } \\
\text { Trigger was calibration checked again in the } \\
\text { Instrumentation shop on } 12 / 13 \text {, 12/14, and } 12 / 15 \text {; } \\
\text { setpoints are still satisfactory. }\end{array}$ \\
\hline $\begin{array}{l}12 / 15 / 97 \\
\text { morning }\end{array}$ & & $\begin{array}{l}\text { Seismic Shutdown System AY-sS-1A trigger was } \\
\text { re-installed in the field and calibration } \\
\text { checked; setpoint is still satisfactory. } \\
\text { SET AY-SSS-1A }\end{array}$ \\
\hline $\begin{array}{l}12 / 16 / 97 \\
\text { various } \\
\text { times } \\
8: 00 \mathrm{am}- \\
4: 00 \mathrm{pm}\end{array}$ & sti11 SET & \\
\hline $\begin{array}{l}12 / 17 / 97 \\
\text { various } \\
\text { times } \\
8: 00 \text { an }- \\
4: 00 \text { pm }\end{array}$ & sti]l SET & . \\
\hline $\begin{array}{r}12 / 18 / 97 \\
-9: 00 a m \\
\end{array}$ & tripped & trtpped over -night; no reason known. \\
\hline
\end{tabular}


NCR \#-320-001 Interim Disposition

Troubleshooting of AY-Farm AY-SSS-1A Spurious Trips (Continued)

\begin{tabular}{|c|c|l|}
\hline \multicolumn{3}{|c|}{ Date: Saturday 1/10/98 } \\
\hline Time & Status & Comments \\
\hline \hline $10: 00$ am & SET & SET AY-SSS-1A \& 1B \\
\hline $11: 00$ & sti1l SET & AY-PDP-I vol tages: VAB $=474$, VBC $=475$, \\
VCA $=464$
\end{tabular}

\begin{tabular}{|c|c|c|}
\hline \multicolumn{3}{|r|}{ Date: Monday 1/12/98 } \\
\hline Time & Status & Comments \\
\hline $8: 50 \mathrm{am}$ & tripped & $\begin{array}{l}\text { found tripped; no reason known. De-energized } \\
\text { power to AY-SSS-1A battery charger. }\end{array}$ \\
\hline $8: 51$ & SET & SET AY-SSS-1A; note that battery charger is OFF. \\
\hline$-10: 00$ & still SET & note that battery charger is still ofF. \\
\hline 12:00 pm & still SET & \\
\hline$-2: 00$ & still SET & \\
\hline $4: 00$ & still SET & $\begin{array}{l}\text { re-energized power to battery charger; AY-SSS-1A } \\
\text { tripped as expected due to voltage transient. }\end{array}$ \\
\hline $4: 01$ & SET & SET AY-SSS-1A \\
\hline
\end{tabular}


NCR $\#$-320-001 Interim Disposition

Troubleshooting of AY-Farm AY-SSS-IA Spurious Trips (Continued)

\begin{tabular}{|c|c|l|}
\hline \multicolumn{3}{|c|}{ Date: Tuesday 1/13/98 } \\
\hline Time & Status & Comments \\
\hline $10: 30$ am & still SET & $\begin{array}{l}\text { still SET from yesterday afternoon; note that } \\
\text { battery charger is energized. }\end{array}$ \\
\hline $12: 00 \mathrm{pm}$ & still SET & \\
\hline $2: 00$ & still SET & $\begin{array}{l}\text { Pit chiller system pump and bypass pump operated } \\
\text { for checking glycol piping. }\end{array}$ \\
\hline $4: 00$ & still SET & \\
\hline
\end{tabular}

\begin{tabular}{|c|c|l|}
\hline \multicolumn{3}{|c|}{ Date: Wednesday 1/14/98 } \\
\hline Time & Status & Comments \\
\hline \hline $10: 00$ am & still SET & \\
\hline $12: 00 \mathrm{pm}$ & still SET & \\
\hline $2: 00$ & sti1l SET & \\
\hline $4: 00$ & still SET & \\
\hline
\end{tabular}

\begin{tabular}{|c|c|l|}
\hline \multicolumn{3}{|c|}{ Date: Thursday 1/15/98 } \\
\hline Time & Status & Comments \\
\hline $9: 30 \mathrm{am}$ & TRIPPED & found tripped; trigger had to be reset \\
\hline $9: 32 \mathrm{pm}$ & SET & $\begin{array}{l}\text { trying to arrange for instrumentation support } \\
\text { for further troubleshooting }\end{array}$ \\
\hline $2: 00$ & still SET & \\
\hline $4: 00$ & still SET & \\
\hline
\end{tabular}


NCR \#W-320-001 Interim Disposition

Troubleshooting of AY-Farm AY-SSS-1A Sourious Trips (Continued)

\begin{tabular}{|c|c|l|}
\hline \multicolumn{3}{|c|}{ Date: Tuesday 2/3/98 } \\
\hline Time & Status & Comments \\
\hline \hline $10: 00$ am & TRIPPED & found tripped; trigger had to be reset \\
\hline $10: 02 \mathrm{pm}$ & SET & \\
\hline
\end{tabular}

\begin{tabular}{|c|l|l|}
\hline \multicolumn{2}{|c|}{ Date: Thursday 2/5/98 } \\
\hline Time & Status & Comments \\
\hline \hline $9: 00$ am & & $\begin{array}{l}\text { tripped system for cal ibration check; } \\
\text { calibration check performed by instrument tech } \\
\text { Pat Hurson; setpoints are satisfactory. }\end{array}$ \\
\hline $10: 30$ am & SET & \\
\hline
\end{tabular}

\begin{tabular}{|c|c|l|}
\hline \multicolumn{3}{|c|}{ Dates: Sunday $2 / 8 / 98$} \\
\hline Time & Status & Comments \\
\hline $11: 00$ am & still SET & \\
\hline
\end{tabular}

\begin{tabular}{|c|c|l|}
\hline \multicolumn{3}{|c|}{ Date: Tuesday 2/10/98 } \\
\hline Time & Status & Comments \\
\hline \hline $8: 00$ am & st117 SET & Set AY-5SS-1B \\
\hline
\end{tabular}

\begin{tabular}{|c|c|l|}
\hline \multicolumn{2}{|c|}{ Date: Friday 2/13/98 } \\
\hline Time & Status & Comments \\
\hline \hline $12: 30 \mathrm{pm}$ & St117 SET & AY-SSS-1B al so still set \\
\hline
\end{tabular}


NCR \#W-320-DOl Interim D1sposition Troub] eshoating of AY-Farm AY-SSS-1A Spurtous Trips (Continued)

\begin{tabular}{|c|c|l|}
\hline \multicolumn{3}{|c|}{ Date: Tuesday 2/17/98 } \\
\hline Time & Status & Comments \\
\hline \hline $9: 00$ am & TRIPPED & found tripped; trigger had to be reset \\
\hline $9: 02 \mathrm{am}$ & SET & \\
\hline $12: 00 \mathrm{pm}$ & still SET & \\
\hline $2: 00$ & still SET & \\
\hline $4: 00$ & still SET & \\
\hline
\end{tabular}

\begin{tabular}{|c|c|l|}
\hline & \multicolumn{2}{|c|}{ Date: Wednesday 3/11/98 } \\
\hline Time & Status & Comments \\
\hline \hline $11: 30 \mathrm{pm}$ & & $\begin{array}{l}\text { electricians installed transient voltage } \\
\text { suppressor for AY-SSS-1A. }\end{array}$ \\
\hline $11: 32 \mathrm{pm}$ & SET & re-energized power and set system \\
\hline $2: 00$ & still SET & \\
\hline $4: 00$ & still SET & \\
\hline
\end{tabular}

As of Tuesday 3/24/98 at $-10: 00$, the AY-SSS-1A system has been set for 13 days with No trips. The Seismic Shutdown System AY-SSS-IA including the associated seismic trigger is considered operational.

Troubleshooting supervised by TJ Kasnick.

This summary prepared by TJ Kasnick. 


\section{POWER PROTECTION PRODUCTS}

\section{PQI SERIES SURGE SUPPRESSOR/RFI FILTERS}

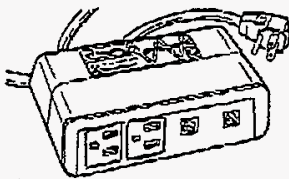

Pol-11190 Deskiop God Performance

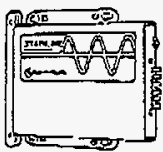

PQI-3120H Hard Wiros Industrial Hard Wire

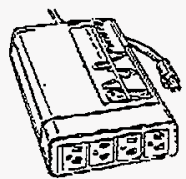

PQL-2115 Destap

- Better Petomance

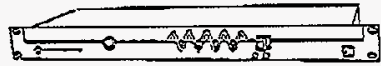

Pol-2115R Rack Mount

-1)-inch Rack Mount

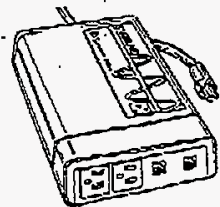

POI-3115D Deskeo -Supcrior Pertomeneo

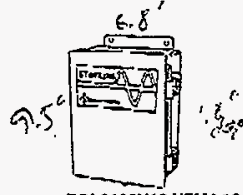

POI-3120NT2 NEMA TR Heets NEMA 12

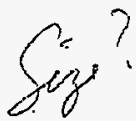

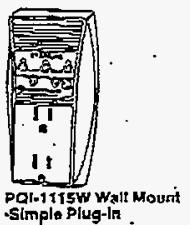

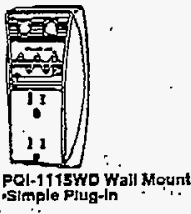

- All Units are Covered by a Full 10-yoar Warranty.

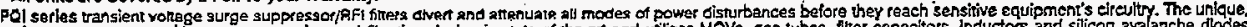

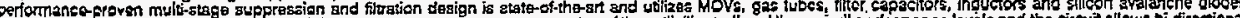
ocpending upon the series solectod. Hybrid design tochnology offers usors a choice of "gcos", "better" and "superior" pertormance levelas and the oircuit allaws bi-cirectional

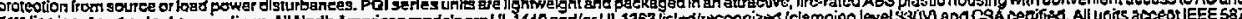

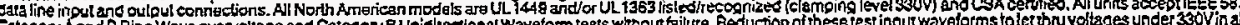

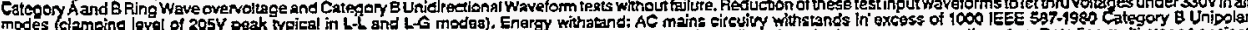

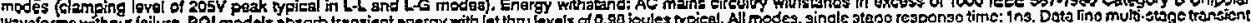

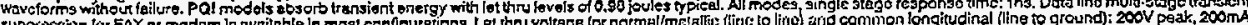

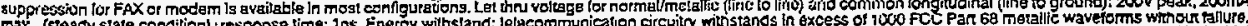

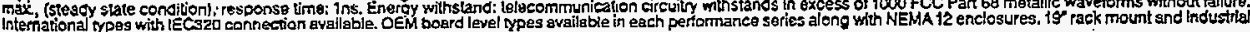
mardwired style conisigurations.

1000 SERIES - GDOD PERFORMANCE HODELS

\begin{tabular}{|c|c|c|c|c|c|c|c|c|c|}
\hline \multirow{3}{*}{$\begin{array}{c}\text { stoek } \\
\text { No. }\end{array}$} & \multirow[b]{3}{*}{ TYpв } & \multirow[b]{3}{*}{ Styie } & \multirow[b]{3}{*}{ Volta } & \multirow[b]{3}{*}{ Amps } & \multicolumn{3}{|c|}{ Hecegtacles } & \multirow{3}{*}{$\begin{array}{c}\text { clrcult } \\
\text { Breaker }\end{array}$} & \multirow[b]{3}{*}{ Each } \\
\hline & & & & & \multicolumn{2}{|c|}{$A C$} & \multirow{2}{*}{$\begin{array}{l}\text { RII1 } \\
\text { Oty. }\end{array}$} & & \\
\hline & & & & & Cly. & Sryle & & & \\
\hline $\begin{array}{l}57172964 \\
51 F 2985 \\
9653491 \\
96 F 3492 \\
95 F 3493\end{array}$ & 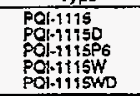 & $\begin{array}{l}\text { Deskncp } \\
\text { Desktoo } \\
\text { Desktop } \\
\text { Wal.-Mosnt } \\
\text { Wall-Mount }\end{array}$ & $\begin{array}{l}120 \\
120 \\
120 \\
120 \\
120\end{array}$ & $\begin{array}{l}15 \\
15 \\
15 \\
15 \\
15 \\
\end{array}$ & $\begin{array}{l}4 \\
2 \\
2 \\
6 \\
2 \\
2 \\
2\end{array}$ & $\begin{array}{l}5-15 \pi \\
5-159 \\
5-15 R \\
5-15 R \\
5-15 R \\
\end{array}$ & $\begin{array}{c}\dddot{2} \\
\dddot{2} \\
\dddot{2}\end{array}$ & $\begin{array}{l}\text { Yos } \\
\text { No } \\
\text { Yes } \\
\text { No } \\
\text { No }\end{array}$ & $\begin{array}{r}59.73 \\
64.08 \\
.64 .08 \\
.38 .01 \\
42.36\end{array}$ \\
\hline$\therefore i$ & & $\cdot$ & ERाES- & TERPEAF & ANCE & ELS & & & \\
\hline 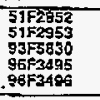 & $\begin{array}{l}\text { PQl-2115 } \\
\text { Poj-2115D } \\
\text { POl-2310 } \\
\text {. POl-2915BR } \\
\text {. POl-2310R .. }\end{array}$ & $\begin{array}{l}\text { Desktop } \\
\text { Deskiop } \\
\text { Desktop } \\
\text { piack-Mount } \\
\text { Pack-Mount }\end{array}$ & $\begin{array}{l}120 \\
120 \\
200 \\
130 \\
230\end{array}$ & $\begin{array}{l}12 \\
15 \\
10 \\
15 \\
.10\end{array}$ & $\begin{array}{l}4 \\
2 \\
3 \\
8 \\
0 \\
\end{array}$ & 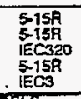 & $\begin{array}{c}\ddot{z} \\
\cdots \ddot{z}\end{array}$ & $\begin{array}{l}\text { Yes } \\
\text { No } \\
\text { Yes } \\
\text { Yes } \\
\text { Yes }\end{array}$ & $\begin{array}{l}707.52 \\
129.24 \\
194.40 \\
225.98 \\
313.86\end{array}$ \\
\hline & & & NES - & RIOR PER & RANCE & DELS & & & \\
\hline 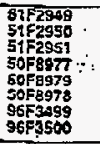 & 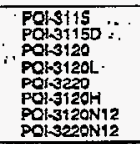 & $\begin{array}{l}\text { Deskfop } \\
\text { Doshop } \\
\text { Dorktop } \\
\text { Desktop } \\
\text { Desktop } \\
\text { Hard Wired } \\
\text { NEMA 12 } \\
\text { NEMA 12 }\end{array}$ & $\begin{array}{l}120 \\
120 \\
120 \\
120 \\
240 \\
120 \\
120 \\
240\end{array}$ & $\begin{array}{l}12 \\
15 \\
20 \\
20 \\
20 \\
20 \\
20 \\
20 \\
20\end{array}$ & $\begin{array}{c}4 \\
2 \\
1 \\
1 \\
1 \\
\cdots \\
\cdots \\
\ldots\end{array}$ & $\begin{array}{c}-5-15 G \\
5.15 R \\
5+20 R \\
15-20 R \\
6-20 R \\
\cdots \\
\ldots . \\
\ldots \\
\end{array}$ & $\begin{array}{l}\cdots \\
\cdots \\
\cdots \\
\cdots\end{array}$ & $\begin{array}{l}\text { Yes } \\
\text { No } \\
\text { No } \\
\text { No } \\
\text { Yes } \\
\text { No } \\
\text { No }\end{array}$ & $\begin{array}{l}750.85 \\
161.82 \\
183.54 \\
237.84 \\
216.14 \\
194.41 \\
248.74 \\
281.28\end{array}$ \\
\hline
\end{tabular}




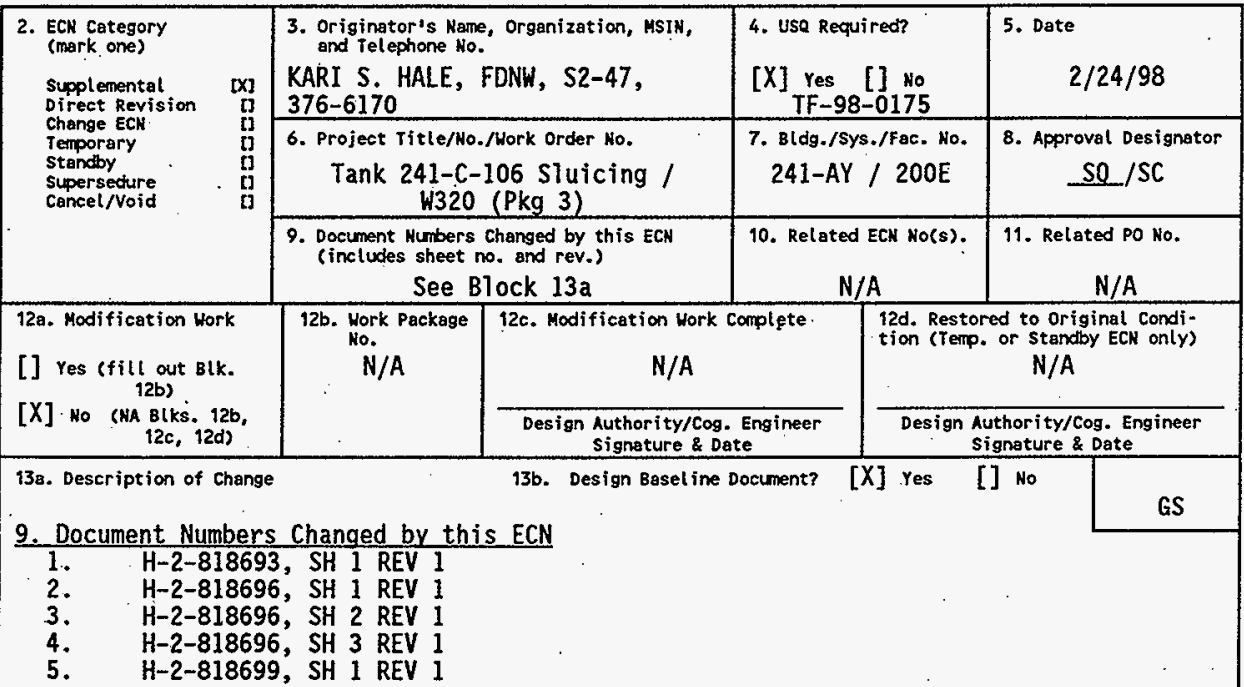

See continuation sheet for Description of Change.

14a. Justification (mark one)

$\begin{array}{lllllll}\text { Criteria Change } & {[]} & \text { Design Improvemerit } & {[X]} & \text { Environmental } & \text { [] } & \text { Facilfty Deactivation [] } \\ \text { As-Found } & {[]} & \text { Facilitate Const } & {[]} & \text { Const. Error/Onission } & \text { [] } & \text { Design Error/Omission }\end{array}$

14b. Justification Details

Support installation of AY-Farm electrical equipment; install Transient Voltage Suppressor in-1ine before Seismic Detector battery charger for AY-SSS-1A. No calculations are affected. An independent review was performed by FDNW per HNF-PRO445.

15. Distribution (include name, MSIH, and no. of copies)

$\mathrm{CDC}, \quad \quad$ 2-53, 1

TJ Kasnick, S2-47, 1

JW Bailey, S2-48, 1

JM Jones, S5-13, 1

Project Files, Rl-29, 1

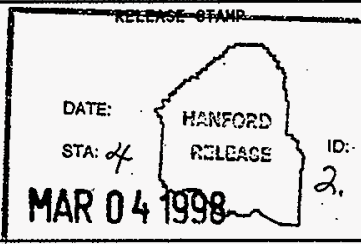


HNF-SD-W320-ATR-007, Rev. 0

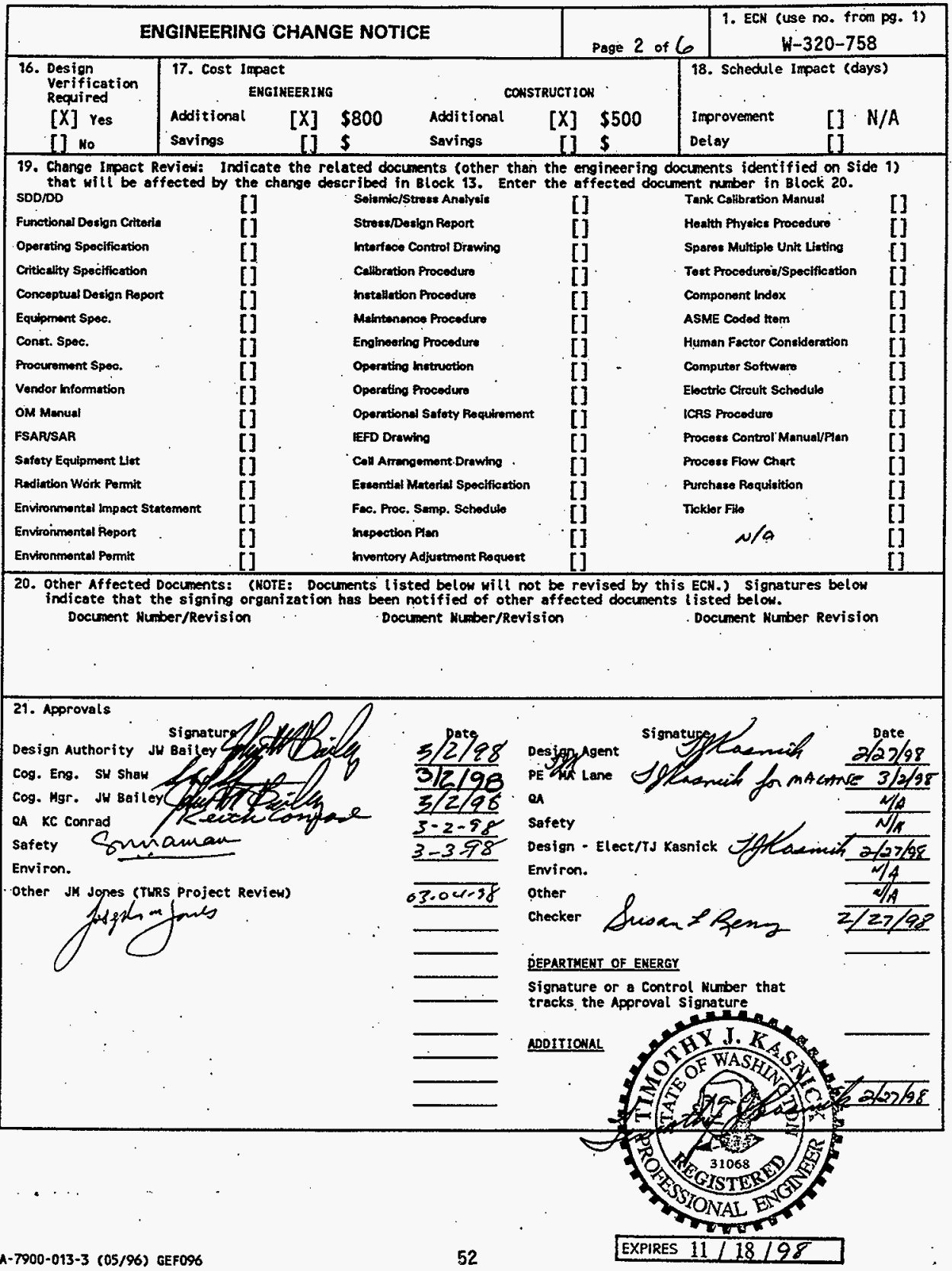


HNF-SD-W320-ATR-007, Rev. 0

ENGINEERING CHANGE NOTICE CONTINUATION SHEET

\begin{tabular}{|c|c|}
\hline & ECN $\mathrm{H}-320-758$ \\
\hline 8 & Date $2 / 2$ \\
\hline
\end{tabular}

\section{3a. Description of Change}

1. H-2-818693, SH 1:

a. Zone B/C-6/7: Revise One Line for the Mini Power Panel AY102-PP1 to add Local Panelboards in buildings 241-AY-51A and 241-AY-51B as shown on page 5 of this ECN.

2. $\mathrm{H}-2-818696, \mathrm{SH} 1$ :

a. Zones D/E-8 \& D/E-5: Change Battery Charger JC-0621 and JC-0622 to show correct power source, show Transient Voltage Supperessor for JC-0621, and change text for HS-06211A (two places) from "REMOTE TRIP" to "EMERGENCY TRIP" as shown on page 5 of this ECN.

3. $\mathrm{H}-2-818696, \mathrm{SH} 2$ :

a. Add "PARTIAL ONE-LINE DIAGRAM" as shown on page 5 of this ECN.

4. H-2-818696, SH 3:

a. Zones F-5, D/E-5/6, \& D-7/8: Add Transient Vo7tage Suppressor Enclosure, and revise equipment layout and conduit routing on ENLARGED PLAN, SECTION $A$ and SECTION B as shown on page 6 of this ECN. 
HNF-SD-W320-ATR-007, Rev. 0

ENGINEERING

CHANGE NOTICE CONTINUATION SHEET

Page 4 of 6

ECN $\mathrm{H}-320-758$

Date $2 / 24 / 98$

5. H-2-818699, SH 1:

a. Zone D/E-3/7: Revise text in specified columns for wire runs \#-22, \#-23, \#-34 \& \#-35, and add wire run \#-34A as shown below:

\begin{tabular}{|c|c|c|c|c|c|c|c|}
\hline $\begin{array}{l}\text { WIRE } \\
\text { RUN } \\
\text { NO }\end{array}$ & $\begin{array}{l}\text { NO OF } \\
\text { WIRES }\end{array}$ & $\begin{array}{c}\text { SIZE } \\
\text { OF } \\
\text { WIRES }\end{array}$ & $\begin{array}{c}\text { TYPE } \\
\text { OF } \\
\text { WIRES }\end{array}$ & FROM & VIA & TO & WIRE NUMBERS \\
\hline$\#-22$ & & & & & & $\begin{array}{l}\text { 241-AY-51A } \\
\text { (LOCAL PANEL) }\end{array}$ & \\
\hline$\#-23$ & & & & & & $\begin{array}{l}\text { 241-AY-51B } \\
\text { (LOCAL PANEL) }\end{array}$ & \\
\hline$\#-34$ & & & & $\begin{array}{l}\text { 241-AY-51A } \\
\text { LOCAL PANEL } \\
\text { CKT } 4\end{array}$ & NIPPLE & $\begin{array}{l}\text { TRANSIENT } \\
\text { VOLTAGE } \\
\text { SUPPRESSOR }\end{array}$ & CKT 4-H, -N, -GND \\
\hline$\#-34 A$ & 2 & $\# 12$ & 7 & $\begin{array}{l}\text { TRANSIENT } \\
\text { VOLTAGE } \\
\text { SUPPRESSOR }\end{array}$ & $*-3 P 32$ & $\begin{array}{l}\text { AY-SSS-1A TBI } \\
\text { (BATTERY } \\
\text { CHARGER) }\end{array}$ & CKT 4-H, -N, -GND \\
\hline$\#-35$ & & & & $\begin{array}{l}\text { 241-AY-51B } \\
\text { LOCAL PANEL } \\
\text { CKT } 4\end{array}$ & & $\begin{array}{l}\text { AY-SSS-1B TB1 } \\
\text { (BATTERY } \\
\text { CHARGER) }\end{array}$ & CKT 4-H, -N, -GND \\
\hline
\end{tabular}

Field Note: (not to be incorporated) Relabel conductors for wire run \#-35. 


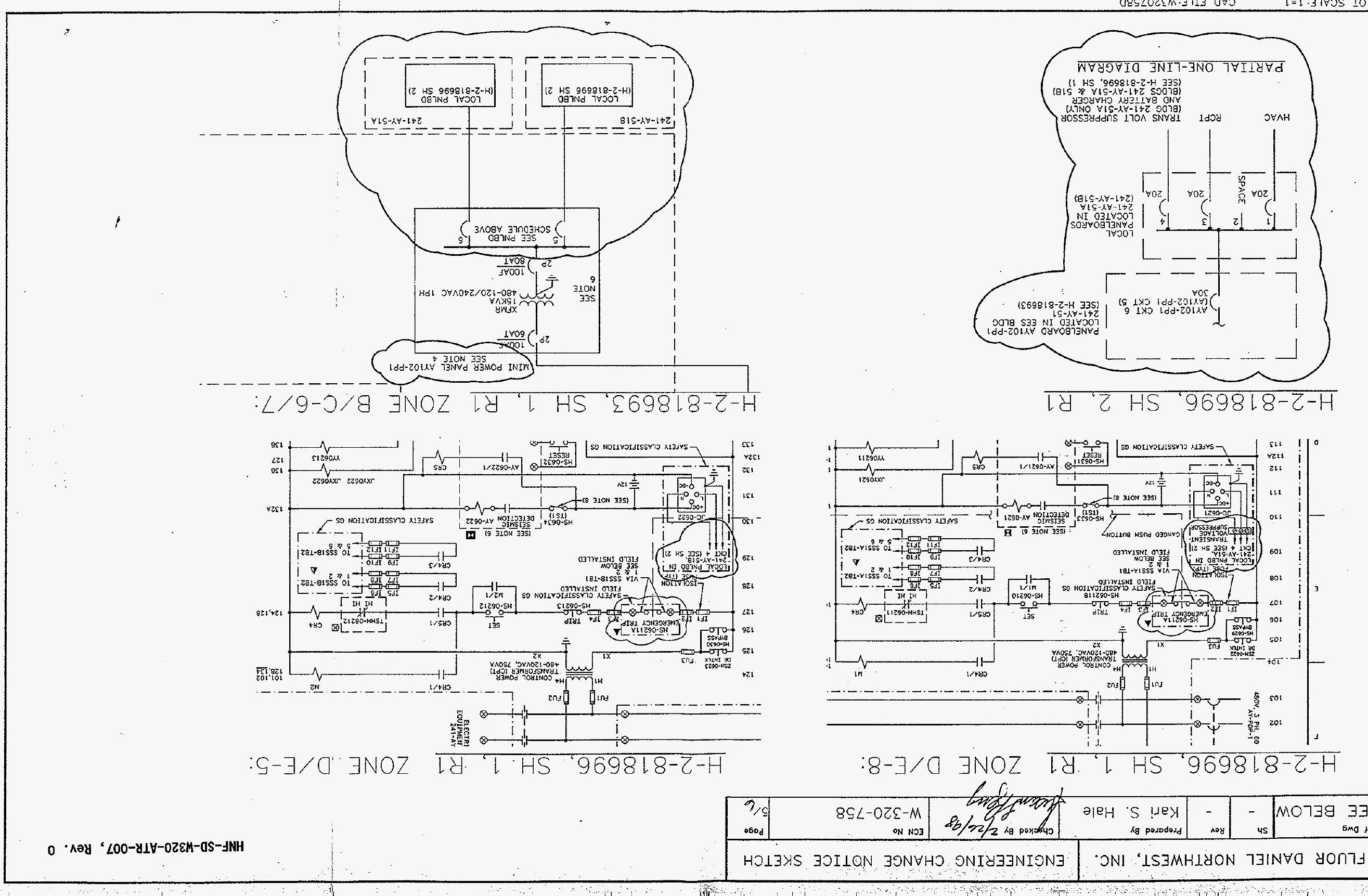


